\title{
A SEPARAÇÃO DE PODERES EM PAIISES PRESIDENCIALISTAS: A AMÉRICA LATINA EM PERSPECTIVA COMPARADA ${ }^{1}$
}

\author{
Luís Gustavo Mello Grohmann \\ Universidade Federal de Santa Maria
}

\begin{abstract}
RESUMO
Este artigo discute a separação de poderes nos países presidencialistas da América Latina, ressaltando seus pressupostos teóricos e evidenciando o balanço entre os poderes Executivo e Legislativo, bem como suas implicações para o aperfeiçoamento democrático. Conclui que a maioria dos países presidencialistas latino-americanos apresenta predomínio do Legislativo com importantes casos desviantes, como Brasil, Chile e México, onde há ou conflito entre poderes ou predominio do Executivo.
\end{abstract}

PALAVRAS-CHAVE: separação de poderes; presidencialismo; relações Executivo-Legislativo; América Latina; politica comparada.

\section{INTRODUÇÃO}

A década de 80 do século passado representou para a América Latina o momento maior de sua democratização. A queda da maioria dos estados autoritários não apenas derrotou atores políticos históricos como também propiciou o surgimento de um novo desafio: dotar os regimes nascentes de um quadro institucional que, além de ser mero instrumento das forças em luta, fosse capaz de garantir a continuidade do processo democrático. É certo que essa marcha apresentou e apresenta retrocessos, tais como o período Fujimori, dúvidas, como o regime de Chávez, e sobrevivências, como restos de autoritarismo no Chile. Contudo, salientamos, o processo de institucionalização das regras de funcionamento da democracia assumiu um papel importante nessa etapa latino-americana. Daí a relevância do estudo sobre o aparato consti-

\footnotetext{
1 Este trabalho foi originalmente apresentado na mesaredondaConsolidaçãoda democracia: enfoquesteónicoseprocessos político-institucionais, realizada durante o Seminário Intemacional de Ciência Política: Política desdeel Sur, entre 3 e 5 de outubro de 2001 na Universidade Federal do Rio Grande do Sul (UFRGS). O evento foi organizado como patrocínio do Departamento de Ciência Política da UFRGS, do seu Programa de Pós-Graduação emCiência Política da Associação das Universidades do Grupo de Montevidéu. Agradeço aos comentários de Fabiano Santos, Jairo Nicolau e Reginaldo Perez.
}

tucional que formata as relações entre os atores políticos.

Nosso trabalho examina a separação de poderes nos países da América Latina que têm como sistema de governo o presidencialismo. Comparamos as disposições em geral vigentes nas constituições da década de 90, mais especificamente no ano de 1999, disposições essas que são responsáveis pelo balanço de poder entre executivos, legislativos e judiciários, enfocando com grande ênfase a relação Executivo-Legislativo.

Partimos do pressuposto de que as instituições políticas exercem efeitos sobre o resultado dos conflitos nos quais atores e agentes da sociedade, politicamente organizados, colocam-se como protagonistas. Se considerarmos que as instituições políticas voltaram a se constituir em foco importante de pesquisas, então isso implica concordar que elas são importantes para o processo político, em especial, para a ação política e para a tomada de decisão. Se desempenham algum papel, deve ser demonstrado qual papel e por que assim o é. Dessa forma, não assumimos a redução das instituições à impotência diante do primado das ações.

Portanto, a separação de poderes não pode ser ignorada como um debate antigo, pronto para ser jogado às traças da história política, na medida em que a ação política pura não elide a institucio- 
nalidade e seus efeitos. Se as instituições importam, a separação dos poderes, que começa ou como princípio normativo de condução da ação coletiva ou como resultado direto e não intencional da ação política, ainda merece ser debatida e investigada. Uma implicação suficiente para justificar a investigação sobre a separação de poderes diz respeito à capacidade de um sistema de governo gerar decisões tendo em vista a quantidade e forma de relação entre $n$ diferentes atores políticos. De outro lado, como aponta Tsebelis (1998, p. 3356), as instituições formais, tais como aquelas que formam o complexo do sistema de governo, abrem a possibilidade de cálculo racional e estratégico por parte dos atores.

A perspectiva de valorização das instituições políticas tomou novo fôlego na década passada em parte pelo refluxo de duas concepções: a marxista, que alocava na sinergia do processo econômico com o processo social as determinações da disputa política, e a comportamentalista, pela qual a ação era explicada em termos quase que exclusivos pela referência a valores, crenças e costumes dos atores.

Três grandes temas foram retomados nos estudos sobre instituições políticas: o sistema eleitoral, o sistema partidário e o sistema de governo. No Brasil, o debate colou-se à própria dinâmica conjuntural, na medida em que, saída das brumas autoritárias, a nação buscou refletir e remodelar suas instituições no sentido da democratização (por exemplo, TRINDADE, 1992; LAMOUNIER \& NOHLEN, 1993; KINZO, 1993). Não foi diferente em diversos países latino-americanos, os quais, em parte pelos novos tempos na arena internacional (fim da Guerra Fria, rechaço a sistemas autoritários), em parte por suas dinâmicas internas, reconstruíram ou fundaram sistemas políticos orientados pela perspectiva da democracia representativa.

Para tanto assumiu importância a definição do arcabouço constitucional, o qual, trivialmente, define as regras da competição política e do como governar. O desafio, que ainda perdura, é determinar quais arranjos constitucionais possibilitam que práticas democráticas sejam seguidas e consolidadas, afastando o máximo possível a chance de que regimes autoritários voltem a surgir no cenário político.

Como apontou Przeworski (1994), a democracia representativa, para perdurar, deve contar com a adesão dos atores políticos aos seus valores e regras básicas; dentre eles o mais importante é aceitar que partidos perdem eleições. Outra tradição, contudo, aponta que os arranjos do sistema de governo são importantes no sentido de que devem proporcionar governabilidade, permitindo que o sistema fique estável, não sendo perturbado pela paralisia decisória. Nesse sentido, o presidencialismo foi sistematicamente atacado, dentro e fora do Brasil (POWELL, 1982; LAMOUNIER, 1991; LINZ \& VALENZUELA, 1994). De outro lado, algumas vozes chamaram a atenção para o fato de que a diversidade de tipos de presidencialismo conduz ao reconhecimento de que o sistema pode ser instável ou estável, dependendo diretamente de suas instituições e seu contexto político (SHUGART \& CAREY, 1992; MAINWARING \& SCULLY, 1995; MAINWARING \& SHUGART, 1997). Foram tratadas também as diferentes combinações do sistema de governo com sistema eleitoral e partidário, as quais podem gerar diferentes resultados tendo em vista a estabilidade governativa (MAINWARING, 1993; JONES, 1995).

A análise do sistema constitucional presidencialista exige uma abordagem que recupere os pressupostos da separação de poderes. Na seção seguinte resgatamos, brevemente, a trajetória do conceito de separação de poderes e os elementos que compõem o seu universo. As seções posteriores tratam do modelo teórico para análise da separação de poderes, da metodologia empregada e os resultados obtidos a partir da comparação das constituições latino-americanas.

\section{AS TEORIAS DA SEPARAÇÃO DE PODE- RES}

\section{II.1 Os clássicos: Locke, Montesquieu e os Federalistas}

Discutir o sistema de governo em democracias representativas a partir de suas instituições implica antes de mais nada reconhecer os fundamentos teóricos que animam o projeto prático. Em sistemas presidencialistas, em especial, a questão da separação de poderes coloca-se como angular. A simples existência desses arranjos por si mesma já seria suficiente para justificar a reflexão a partir desse ponto de vista. No entanto, julgamos que no século que se inicia, com o aumento da quantidade de países que buscam constituíremse como democráticos, com o incremento da circulação de informação (principalmente via internet), com o avanço da defesa dos direitos 
fundamentais da pessoa humana, a institucionalidade política assume uma importância crucial como fator de encaminhamento para a resolução de conflitos. De outro lado, tais transformações aliadas às transformações no mundo do trabalho e da cultura, bem como ao agravamento das condições sociais de vida das populações (tendo em vista as políticas estabelecidas pelos governos, estas, muitas vezes, em obediência às indicações de organismos internacionais) - apresentam o dilema da participação versus decisão governamental, revelando a crise do tradicional Estadonação que emergiu do pós-Guerra. O uso de fórmulas institucionais que regulam uma participação ampliada da sociedade na formulação e aplicação de políticas públicas (Porto Alegre, Chicago, Wisconsin; cf. FUNG \& WRIGHT, 1999) podem auxiliar no redimensionamento dos esquemas de decisão política no campo do Estado.

Contudo, os fundamentos desse Estado encontram-se nas teorias que, no passado, empreenderam a tarefa de pensar a solução política para a disputa entre os interesses e os poderes, regulando a participação da sociedade e limitando ou justificando o poder do Estado. O campo da política, ciência e teoria, é aquele que, por excelência, combina o rigor da ciência com a discussão clara dos pressupostos normativos. Conforme Sola (1999, p. 30), a ressignificação do Estado como autoridade democrática implica um esforço normativo no sentido de alcançar os elementos de legitimação e estabelecimento de metas coletivas.

O problema constitucional suscitado é aquele que questiona a construção do sistema de governo e suas relações com os sistemas eleitoral e partidário. Os atuais estados-nação do mundo democrático foram construídos sob a égide da divisão dos poderes. A divisão dos poderes não é uma técnica institucional que possa ser depreendida totalmente dos aspectos normativos, na medida em que qualquer engenharia constitucional implica alcançar certos objetivos. Em termos de interesses de grupos, objetivos podem ser bons para uns e terríveis para outros; em termos de construção de regimes algumas regras são mais adequadas que outras: certos instrumentos podem ser nitidamente autoritários, outros nitidamente democráticos.

A separação de poderes institucionalmente fixada nasce da confluência histórica da política prática, das disputas entre grupos humanos, e da reflexão sobre essa prática tendo em vista aperfeiçoá-la ou modificá-la. A reflexão sobre o poder dividido apresentou-se desde a Grécia antiga e a principal preocupação que a animou permaneceu ao longo dos tempos: como evitar a tirania. A divisão do poder é uma velha solução. As teorias das formas de governo são as primeiras a identificar o formato dos governos e qual a sua melhor organização. A teoria do governo misto, de longa trajetória, nasce então sugerindo que a melhor forma de governo é aquela que combina as diferentes modalidades de governo (monarquia, aristocracia, democracia), a partir da existência de três corpos: o do monarca, o dos aristocratas e o do povo. Essa repartição tríplice tem, então, como critério mais evidente o número de soberanos governantes (um, poucos e muitos), mas trazendo consigo certa acoplagem aos elementos da formação social do meio onde foram produzidos. O importante, contudo, é a referência à separação de corpos ou agências de poder. Na teoria do governo misto não há a necessária delimitação funcional desses corpos, nem um escopo de especialização; a crença fundamental é de que o poder repartido, por si só, é capaz de limitar a possibilidade do governo absoluto. Tal noção foi ajustada pela teoria do governo equilibrado, já na trajetória inglesa renascentista, que trouxe a idéia de que os poderes, além de serem repartidos em potências parecidas, deveriam controlar um ao outro. Até aí a divisão desses corpos pautava-se pela própria existência das forças sociais politicamente organizadas, catalisadas pelas figuras do Monarca, da Câmara dos Lordes e da Câmara dos Comuns.

A teoria da separação de poderes pura introduz pelo menos uma importante modificação: a atribuição de funções específicas para cada poder. Além disso, como tributária das teorias anteriores, pugna que cada poder não pode imiscuir-se nas atividades relacionadas à função do outro poder, proibindo-se que os ocupantes dos cargos em um e outro poder sejam os mesmos simultaneamente. Para Vile (1998), é o amálgama entre as três teorias (separação de poderes, governo misto e governo equilibrado) que proporciona o surgimento, nas figuras de Locke, Montesquieu e dos Federalistas, da teoria da separação parcial de poderes, na qual é permitido certo grau de compartilhamento funcional, especialmente na função legislativa, isto é, por exemplo, um outro poder (o Executivo) também dispõe de atribuições legislativas, como 
o veto. O resultado desse compartilhamento inscreve-se na perspectiva da teoria do governo equilibrado, em que um poder controla o outro. Tal compartilhamento funcional, entretanto, não é principalmente positivo. É enviesado, no sentido de cumprir uma determinação: ser um procedimento de freio e contrapeso.

Quais são os elementos e os aspectos teóricos que fazem de Locke, Montesquieu e dos Federalistas as referências fundamentais em se tratando da separação de poderes no moderno Estado-nação? Em Locke (1973, p. 82-131), o poder supremo é o poder Legislativo. Contudo, esse poder Legislativo pode estar alocado em diferentes mãos, conforme o regime de governo: se democracia, nas mãos dos funcionários eleitos; se oligarquia, nas mãos de alguns homens; se monarquia nas de um só homem. Esse poder supremo é limitado pelas leis da natureza: o respeito à vida, à liberdade e à propriedade. $\mathrm{O}$ bem público, objetivo maior do poder Legislativo, deve obedecer a esses limites.

Conforme Locke, são três os poderes do Estado: o Legislativo, o Executivo e o Federativo. O Legislativo deve fazer as leis e delegar a execução da justiça. O Executivo divide-se em dois tipos de poder: o Executivo propriamente dito, e o Federativo, que diz respeito às relações com outras nações, estados ou pessoas estrangeiras.

Os poderes do Executivo podem ser melhor detalhados:

1) convoca e estabelece a duração das reuniões do Legislativo;

2) modifica a base de constituição do corpo Legislativo caso este seja eleito, incluindo novos setores ou corrigindo outros, desde que a formação societária tenha sido alterada;

3) tem a prerrogativa, isto é, tendo em vista o bem público (que observa as leis da natureza) pode agir livremente onde a lei não exista e expedir legislação, e/ou atuar contrariamente à lei vigente, independentemente da aprovação do Legislativo. Dessa maneira, a prerrogativa é fazer o bem público sem conformar-se às regras.

Esse último item evidencia a dificuldade de Locke em admitir uma rígida separação de poderes. A proposta de prerrogativa em mãos do
Executivo pode atender ao cuidado do autor em não parecer antimonarquista, dada a existência de um rei ativo e com poderes importantes diante de um Parlamento que é portador da função legislativa. Mas, de todo modo, o importante é que, apesar de afirmar a supremacia do Legislativo, ele defendeu a capacidade do Executivo em executar e legislar à margem desse mesmo poder.

Dois são os critérios lockeanos para separar os poderes: a natureza humana e a natureza da função. $\mathrm{O}$ primeiro afirma que os seres humanos têm fraquezas e que quando os indivíduos dispõem de poder irão abusar dele. Portanto, deve-se dividir o poder, tornando-o mais fraco. Não há afirmação de que é preciso dividir o poder para confrontar duas partes que se autolimitem.

O segundo critério postula que os poderes têm diferentes tempos de atuação. Para fazer as leis não é preciso estar permanentemente reunido, considerando que essa é uma etapa curta, ao passo que as atividades executivas são constantes, necessitando de permanente atenção.

Sua teoria, portanto, apontou a separação dos poderes sem se preocupar com a limitação recíproca entre eles. Somente a prerrogativa do Executivo aproxima-se dessa idéia, como um mecanismo pelo qual se podem corrigir conflitos e injustiças. O interessante é que a capacidade de legislar é um princípio que o Legislativo não pode delegar: ele legisla, não foi feito para produzir legisladores. A separação de poderes aparece fundamentalmente respondendo a um critério funcional, qual seja, a atividade que o poder desempenha ou deve desempenhar tendo em vista a efetivação do bem público.

Montesquieu (1973) foi mais perspicaz em sua teoria. Por ter em vista basicamente a liberdade política - que para ele é a conjunção da liberdade oferecida pela lei (segundo a qual ninguém deve fazer o que a lei proíbe ou ser constrangido a fazer o que a lei não determina) com a tranqüilidade de espírito que o cidadão tem sobre sua segurança pessoal - propôs categoricamente a separação de poderes. É novamente a natureza humana, que ele considera predisposta a abusar dos poderes de que porventura disponha, que está na base da justificativa da separação dos poderes. Somente o poder tem força para barrar o poder. A idéia fundamental é que um poder tenha a capacidade de barrar ao outro de modo a forçar um acordo, e vice-versa, criando a moderação nas decisões e 
gestão do Estado. Evita-se assim o abuso de poder por parte de algum corpo e obtém-se, em decorrência do não-abuso de poder, a liberdade política. A unidade do poder significa a possibilidade de tirania. E basta ao indivíduo estar exposto a essa possibilidade para instaurar-se o temor à sua segurança, redundando em falta de liberdade política.

O critério para estabelecer os poderes diferenciados é funcional, isto é, pela atividade principal de cada um. Essa atividade não se confunde com os instrumentos de que cada poder dispõe ou com características de organização necessária à efetividade na função. Por exemplo, o poder Legislativo estabelece a legislação, mas a manutenção de um corpo Legislativo que preserve o poder dos nobres frente ao povo em geral não é uma função propriamente dita do poder, mas um aspecto que concorre para a efetividade daquela função e que evita o abuso de poder por parte do Legislativo .

Além disso, Montesquieu classificou os três poderes do Estado: o poder Legislativo (fazer as leis); o poder Executivo das coisas que dependem do direito das gentes (paz, guerra, segurança, prevenção de invasões etc.), que é o poder Executivo do Estado; o poder Executivo das coisas que dependem do direito civil (pune os crimes, julga conflitos entre indivíduos etc.), ou seja, o poder de julgar.

Marcado pelo contexto de sua época, a distribuição desses poderes entre diferentes corpos observará os atores sócio-políticos existentes. O Executivo ficaria nas mãos do monarca, o Legislativo nas dos nobres e dos representantes do povo, e o Judiciário em tribunais temporários do povo. É a física do poder. A relação entre setores sociais e constituição dos poderes é inequívoca; por isso a separação do Legislativo em dois corpos, um plebeu e outro nobre, como uma forma de proteger os últimos, obtendo dessa maneira a moderação do Legislativo frente ao Executivo.

A questão nova de Montesquieu frente a Locke diz respeito à introdução da idéia de controle de um poder sobre o outro. O poder contra poder não se constitui somente por duas instâncias que se enfraquecem por abarcar unicamente uma parte das atividades do governo da sociedade (razão defendida por Locke). Antes disso, é a possibilidade de um poder vir a impedir ou punir o abuso do outro. Esses controles são: 1) o veto do Execu- tivo sobre o Legislativo, e 2) compensando a incapacidade do Legislativo em vetar o Executivo, aquele teria o direito de punir os funcionários (ministros, por exemplo) do Executivo. De outro lado existiriam salvaguardas aos poderes para que pudessem continuar sua existência sem se subordinarem à vontade ou a abusos de outro poder. No sentido de proteger os nobres da ação dos tribunais populares, esses seriam julgados de maneira especial, por integrantes da mesma categoria social e do mesmo corpo político. Integrantes do Executivo seriam julgados pelos nobres do Legislativo, em processos iniciados pela Câmara dos plebeus.

Esse arranjo forçaria os integrantes dos poderes a caminhar para um acordo, do contrário o resultado poderia ser a paralisia (idem, p. 160). Ou seja, Montesquieu já previra que a paralisia decisória poderia ser o resultado da separação de poderes, mas, ao invés de considerá-la como um problema, assumiu-a como um incentivo para forçar o acordo entre os poderes, concorrendo para a produção de políticas moderadas, conducentes à liberdade política.

Três outras questões também são relevantes: 1) a origem dos integrantes do poder; 2) o tempo do mandato; e 3) o tipo de trabalho desenvolvido pelos poderes. A primeira questão diz respeito à interdição para os integrantes do Legislativo de virem a constituir o corpo Executivo (idem, p. 159). O francês não esclareceu, contudo, se essa interdição é exclusivamente para ocupação simultânea de cargos nos dois poderes ou somente de extração, isto é, para não ocuparem os dois poderes ao mesmo tempo. O segundo ponto considera que mandatos muito grandes tendem a tornar o povo furioso ou indolente, caso os ocupantes dos cargos estabeleçam políticas ruins. Ou seja, haverá dissociação entre Governo e sociedade, entre governo e representação. O terceiro ponto afirma, de um lado, a singularidade do Executivo, tendo em vista a necessidade de agir rapidamente e, de outro, a não utilidade de reuniões freqüentes do Legislativo no sentido de produzir novas leis. Assim, em Montesquieu, a convocação do Legislativo, seu momento e a duração das reuniões, é demanda que também vem fortemente condicionada pelas necessidades do Executivo, o qual têm poderes de convocação. Ele aprimorou a idéia de separação de poderes, introduzindo o corpo judiciário e a idéia de limitações mútuas. Os Federalistas vieram 
aprofundar sua discussão e foram além, colaborando para instituir o primeiro sistema de governo republicano baseado na separação de poderes.

Madison (MADISON, HAMILTON \& JAY, 1993) partia da absoluta concordância com a separação dos poderes em corpos diferenciados segundo sua atribuição funcional. No entanto, defendeu que não havia proibições em Montesquieu acerca de ingerências parciais nas esferas de atribuição entre um poder e outro, afirmando que o grau de independência entre os poderes proposto pelo francês jamais seria alcançado na prática (idem, p. 333, 338). A interpretação de Madison é de que toda ou a maior parte de um poder não deveria permanecer nas mesmas mãos. Dessa maneira, a tirania traduz-se no momento em que uma pessoa ou um grupo detém os poderes Executivo, Legislativo e Judiciário (idem, p. 332).

Madison enfocou o problema da separação dos poderes como um problema de ocupação, sobre quem exerce o poder e quais são as garantias desse exercício. Preocupou-se em não permitir que grupos articulem-se como maiorias unificadas, capazes de esmagar minorias, gerando políticas calcadas em processos emocionais e não racionais. Deslocou seu foco para promover a assunção do indivíduo como elemento angular do edifício institucional. E falar do indivíduo era falar de interesses e ambições. Os homens não são anjos e agem em torno de seus interesses. Ambição deve frear ambição. Nesse sentido, os cargos dos poderes devem oferecer aos seus administradores os meios constitucionais e os motivos pessoais para resistir ao outro poder e a seus abusos (idem, p. 350).

Madison não confiava nas "barreiras de papel" para conter a "índole abusiva do poder" (idem, p. 338). Dois elementos são vitais para garantir a separação de poderes efetiva: dar meios de independência financeira ao poder e oferecer emolumentos condizentes para os ocupantes dos cargos (motivos pessoais), emolumentos esses não submetidos à vontade flutuante dos outros poderes.

Mas outro aspecto ainda é relativizado por ele: a escolha dos integrantes de um poder por outro (idem, p. 349). Considerou que se fôssemos seguir rigorosamente a proposição da separação de poderes, só haveria uma única fonte de escolha dos integrantes de cada poder: o povo. No entanto, é difícil obter esse padrão, principalmente em relação ao Judiciário. Dois argumentos são invocados para justificar o caso especial desse poder: de um lado, é necessária uma qualificação dos seus integrantes, algo que eleições populares não poderiam suprir; de outro lado, o fato de esses integrantes exercerem mandatos permanentes anula o sentimento de dependência em relação a quem os conferiu.

Essa flexibilização das atribuições e da origem dos integrantes dos poderes é acompanhada pela perspectiva relativista de Hamilton, dessa vez em relação à capacidade de um poder checar. Ao discutir as justificativas da disposição do Senado em aprovar ou não nomes de ministros escolhidos pelo Executivo, considerando o resultado para o balanço da separação de poderes, sua posição era: "Não é fácil encontrar uma resposta muito precisa para uma objeção ela mesma tão pouco precisa. Onde está a medida ou critério de que podemos lançar mão para avaliar o que daria ao Senado um grau de influência grande demais, pequeno demais, ou exatamente o devido? Não seria mais seguro, além de mais simples, deixar de lado esses cálculos vagos e incertos, para examinar cada poder em si mesmo e decidir, com base em princípios gerais, onde ele pode ser depositado com mais vantagem e menos inconveniente?" (idem, p. 422).

Eis o seu método para definir os instrumentos constitucionais de defesa e controle de um poder em relação ao outro. $\mathrm{O}$ resultados são a mistura entre as justificativas de balanceamento de forças sociais, separação de poderes e controles de um poder sobre o outro. Diga-se de passagem que esse último não fica explicitado.

No entanto, certos elementos apontados por Montesquieu estão referidos por Madison com justificativas diferentes. A repartição do Legislativo em duas câmaras sai da justificativa de cunho estamental para adquirir foros de balanceamento de poder: o Legislativo é muito forte, portanto é preciso dividi-lo, equalizando-o com o poder do Executivo, um poder fraco, talvez tanto quanto o Judiciário (idem, p. 350).

Mas as questões tornam-se mescladas e falta precisão. Os Federalistas não explicitam todos os termos de uma teoria que acople separação de poderes com controle e equilíbrio entre poderes. As atribuições constitucionais são tratadas de maneira descontraída ao lado de instrumentos de controle e de balanço entre poderes. 
De toda forma, é importante indicar que os elementos constituintes do que ainda hoje se entende por separação de poderes estão ali contidos, basicamente elencados por Hamilton, que apontou as "convenientes" distribuições de poder existentes na Convenção (idem, p. 423):

1) o Senado poderia designar ministros em conjunto com Executivo (o Executivo escolhe e o Senado aprova);

2) exclusividade da Câmara de Representantes sobre propostas de lei que concedam fundos ao governo;

3) a Câmara de Representantes instituirá os processos de impeachment;

4) a Câmara de Representantes será árbitra em todas as eleições para Presidente que não alcancem sufrágios da maioria absoluta dos eleitores;

5) o Legislativo será responsável pelo recrutamento e regulamentação de frotas e exércitos (idem, p. 436).

Quanto ao Executivo temos que o Presidente:

1) deve ter poder de forçar o Legislativo a reexaminar as propostas de lei por ele aprovadas (veto, mas não absoluto ${ }^{2}$ ) (idem, p. 435);

2) será comandante-em-chefe das Forças Armadas;

3) pode comutar penas e dar perdão a crimes contra os EUA, exceto em caso de impeachment;

4) pode solicitar reunião extraordinária do Congresso, e em caso de desacordo quanto à ocasião, determinar o momento;

5) pode nomear os servidores;

6) é autorizado a receber embaixadores e diplomatas (idem, p. 438);

7) com orientação e aprovação do Senado, pode designar embaixadores, diplomatas e juízes da Suprema Corte.

2 Madison propôs o veto absoluto (MADISON, HAMLTON \& JAY, 1993, p. 351).

\section{II.2 Abordagens contemporâneas}

A teoria sobre a separação de poderes até aqui examinada vem largamente construída a partir de uma visão normativa. Em comum, Locke, Montesquieu e os Federalistas propuseram um sistema de governo que apresentasse corpos institucionais com poderes diferenciados em nome da garantia da liberdade, seja ela econômica ou política.

Como vimos, a separação de poderes dos antigos obedece a duas lógicas: aquela que se preocupa em alocar em cada braço do poder grupos e indivíduos diferenciados e aquela que busca delimitar funções diferenciadas para cada um desses braços. Ambas preocupam-se em armar os poderes com instrumentos de defesa e ataque na preservação de suas prerrogativas e de modificação das decisões do outro.

No século XX, a questão da organização do Estado gravitou em outras proposições. A importância da separação de poderes, a partir da justificativa de garantir a liberdade, viu-se debilitada. Diferentes perspectivas apontaram o aumento dos poderes e atribuições dos executivos frente aos legislativos, tendo em vista a crescente complexidade das sociedades modernas e industriais (HIUTT, 1972; SARTORI, 1996).

A constatação de que partidos políticos disciplinados e homogêneos poderiam burlar a separação de poderes serviu também para turvar sua importância enquanto solução institucional para conflitos políticos (DUVERGER, 1970; DIAMOND, 1986). E, ainda, a crítica que se desenvolveu aos presidencialismos envolveu também a noção de separação de poderes, por meio de uma associação, em nossa opinião, não tão imediata e não tão evidente.

Outras perspectivas colocaram a questão como um reequacionamento de funções, em que o Legislativo tenderia a desenvolver um processo de representação, deixando ao Executivo o governo em sua totalidade, incluindo a normalização mais fundamental da vida social e econômica (AKZIN,1972). A predominância do Executivo no processo político tornaria a questão da separação de poderes um discreto problema de história política.

De outro lado, a discussão da separação de poderes passou a ser subsumida na discussão sobre o presidencialismo e o parlamentarismo. 
Separação de poderes, Presidente frente ao Legislativo, tenderiam ou para a paralisia decisória ou para a predominância do Executivo. A eficiência e a estabilidade estariam nas mãos do parlamentarismo.

Muita confusão é feita com esses termos. Tal como Madison e Hamilton não precisaram com exatidão os aspectos institucionais que eram separação de poderes e controle de um poder sobre outro, também hoje em dia os termos são utilizados quase transitivamente, seja pelo senso comum seja por analistas da política.

No entanto, pelo menos duas perspectivas ${ }^{3}$ ainda hoje tratam da separação de poderes com alguma sistematização, resgatando sua importância institucional no jogo político. A primeira diz respeito à literatura norte-americana que busca examinar o funcionamento do sistema presidencial, justamente a partir da proposição dos Federalistas, a da separação dos poderes. Esse conjunto busca resgatar o presidencialismo americano antes de mais nada como um sistema de separação de poderes, analisando a ação dos atores políticos frente às possibilidades oferecidas pelas instituições, militando na contraposição às correntes que pregam a parlamentarização da vida política americana.

A segunda perspectiva é dispersa, mas tem trabalhos significativos. Situando-se no campo da política comparada, esses trabalhos têm diferentes objetivos mas fazem referências à separação de poderes, seja no contexto do presidencialismo, seja no contexto do parlamentarismo.

Neustadt (1967), C. Jones (1995; 1997) e Fischer (1998) defendem a proposição de que o sistema de governo americano é antes de mais nada um sistema de instituições separadas com poderes compartilhados.

C. Jones (1995) afirma que o sistema americano não é presidencialista, se por presidencialismo considerarmos a existência de um Presidente com fortes poderes, tal como faz Powell (1982). C. Jones (1997) observa que é uma limitação exigir que o sistema presidencialista tenha um Presidente forte frente ao Legislativo. A resultante dessa perspectiva é prever que sempre que um Presidente

\footnotetext{
3 Estão excluídos de nossa análise as análises e teorias relevantes do campo do Direito Constitucional estricto sensu.
}

não tiver força política suficiente o resultado será paralisia decisória e instabilidade do governo. Para o autor, o sistema americano, antes de mais nada, seria separacionista, proporcionando diferentes balanços de poder entre Executivo e Legislativo.

C. Jones $(1995$, p. 8$)$ identificou quatro posições normativo-descritivas de balanço de poder: primazia do Legislativo, primazia do Presidente, governo misto cooperativo e governo misto de adversários.

No balanço do poder entre os dois corpos, os dois primeiros tipos são evidentes. Apontam a dominância clara e inequívoca de um sobre o outro. $\mathrm{O}$ governo misto cooperativo surge quando um mesmo partido controla tanto o Executivo quanto o Legislativo. Tal governo é circunstancial, dependendo do quadro eleitoral e de uma relação específica entre Presidente e líderes. O governo misto de adversários revela poderes eqüipotentes mas altamente competitivos, como por exemplo o contexto do dividido governo norte-americano (o qual não implica não-cooperação, pois partidos diferentes podem cooperar).

Duas dimensões são importantes em Jones: a dimensão institucional, que estrutura, oferece meios e organiza a ação dos atores que ocupam aqueles poderes; e a dimensão política, que traz o comportamento dos atores.

A sua proposição permite darmos um passo a mais na caracterização do balanço do poder entre Executivo e Legislativo a partir da separação de poderes. Desde de seu ponto de vista temos que o sistema norte-americano é flexível na constituição desse balanço. Não cristalizaria a dominância ou poder de um sobre o outro mas permitiria um conjunto de soluções conforme (1) a habilidade e projeto do Presidente, e conforme (2) o espectro político do Legislativo. O processo de constituição da agenda (entendida em termos amplos), no sentido de temas e propostas constituintes dos projetos, sejam do Executivo sejam do Legislativo, é central no estabelecimento desse balanço.

Dessa maneira, as análises de Mayhew (1991), que provam não ser o governo dividido gerador de paralisia decisória, ou de Bond e Fleischer (1990), em que fica demonstrado que os representantes se perfilam a favor e contra o governo de maneira a formarem 4 grupos (do mesmo partido do Presidente a favor deste; de partido diferente do Presidente a favor deste; do mesmo 
partido do Presidente contra este; e de partido diferente do Presidente contra este), vêm corroborar que as premissas federalistas de separação de poderes efetivam-se na prática.

Fischer, por seu turno, traça a história da constituição da separação de poderes nos EUA, demonstrando que o modelo de predominância do Legislativo gradativamente vai cedendo lugar a um sistema no qual as partes gozam de grande autonomia e independência, mas constrangidas a um governo conjunto: "Separação mas interdependência, autonomia mas reciprocidade" (FISCHER, 1998, p. 5). Chama a atenção para a diferença entre o sistema de separação de poderes e o sistema de freios e contrapesos: "Dois princípios, aparentemente irreconciliáveis, operam lado a lado: (I) a separação de poderes e (II) o sistema de checks and balances. Longe de serem contraditórios, eles completam e auxiliam um ao outro. Uma instituição não pode checar a menos que tenha alguma medida de independência, e não pode reter independência sem o poder para checar" (Jackson apud FISCHER, 1998, p. 5; idem, p. 6).

A separação de poderes é percebida como independência entre duas partes. Isso significa que uma parte - com formas de existência que não dependem da outra - dispõe de poderes próprios, os quais, para serem empregados, não necessitam de sanção de qualquer outro. Já o sistema de freios e contrapesos significa que uma parte tem o poder de verificar as ações da outra, checar e balancear, e, ainda, bloquear ou obstaculizar as ações da outra. A questão contida na construção da armadura institucional do sistema de governo é como estabelecer o equilíbrio entre ter poderes independentes e autônomos e a capacidade de circunscrever o outro.

A teoria que justifica o arranjo foi examinada anteriormente. Para evitar a tirania de um poder, não basta apenas separar o poder, deixando-o mais fraco. É preciso que um vigie o outro, não permitindo a extrapolação de suas atribuições. Mas o problema se complexifica. $\mathrm{O}$ que ocorre é que a ação dos poderes não se limita a evitar a extrapolação dos poderes instituídos, mas alcança a produção de políticas. Conforme C. Jones (1997), os corpos de poder passam a competir em um ambiente de potências compartilhadas, buscando o estabelecimento de suas políticas. Mesmo o poder judiciário também exerce um papel sobre o fazer político, como, por exemplo, ao julgar as inconstitucionalidades das ações dos outros poderes.

Dessa forma, a limitação de um poder sobre o outro diz respeito também à disputa que se estabelece entre os projetos políticos que os ocupantes de um e outro poder defendem. Há dois movimentos: de defesa de seu projeto, que pede autonomia, e de fazer com que ele seja implantado, que exige a derrota ou acomodação do projeto diferenciado. A agenda política passa a desempenhar um papel fundamental no jogo entre os poderes.

Fischer (1998, p. 6-7) define algumas medidas de salvaguarda para a separação de poderes existentes nos EUA:

1) a não-permissão para que representantes do Legislativo sejam nomeados para cargos na Administração e nem que os ocupantes de cargos tornem-se representantes no Congresso;

2) o Congresso é proibido de passar projetos que provoquem a perda dos direitos civis dos condenados, ou usurpar o Judiciário, por exemplo, ao provocar situações de punição sem processo;

3) a imunidade para os legisladores;

4) o Congresso não pode reduzir a remuneração do Presidente e dos juízes;

5) deve ser assegurada a existência de poderes distintos no processo de orçamento.

Examina também os três poderes exclusivos do Presidente nos EUA: poder para nomear, poder para negociar com nações estrangeiras, poder para perdoar.

O que vemos em Fischer é que também ele não esclarece exatamente os âmbitos de separação de poderes e de freios e contrapesos. As medidas de salvaguarda dizem respeito à manutenção da separação, assim como os poderes exclusivos. É claro que esse não é seu objetivo. Tal como Jones, pretende verificar o comportamento dos atores frente à institucionalidade, tomando casos ad hoc.

Instituições separadas são estruturas que existem sem depender uma da outra. Poderes compartilhados são poderes que estão ao mesmo tempo disponíveis para o Legislativo e para o Executivo. Parece estranho ao ordenamento da separação de poderes, que afinal propõe poderes separados para 
corpos separados. Contudo, se ignorarmos a diferenciação exata entre os poderes e considerarmos a força do poder disponível para cada parte veremos que ambos dispõem de poderes que apresentam duas características: são potentes, no sentido de produzir resultados efetivos em decorrência da ação empreendida, e são flexíveis no uso, isto é, conforme o estilo, a agenda e o programa de cada parte são produzidos diferentes tipos de relação entre elas.

O Presidente norte-americano não dispõe de poderes Legislativos (a exceção é o veto). Depende do partido, das lideranças legislativas para encaminhar suas necessidades legislativas. Não está desarmado, contudo, para realizar sua agenda. Jones e Fischer salientam o campo da negociação entre os atores e do jogo político propriamente dito imerso em determinadas conjunturas. Porém anotamos que esse espaço de compartilhamento pode ser melhor descrito. Poderes Legislativos, poderes executivos, poderes de julgar são razoavelmente identificáveis. Mais adiante vamos tratar desse ponto.

A perspectiva comparativa que resgata a separação de poderes não a examina de maneira exclusiva mas dentro de um conjunto de questões que buscam estabelecer a comparação entre diferentes países e sistemas. De um lado temos Shugart e Carey e, de outro, Lijphart.

Shugart e Carey (1992) examinam basicamente a relação entre presidentes e legislativos a partir da conexão entre desenho constitucional e "dinâmica eleitoral". A questão da separação de poderes é posta como cerne do conceito de presidencialismo, em respeito à posição de Madison. No entanto, conforme eles, os poderes nunca estão plenamente separados no presidencialismo.

Esses autores ainda afirmam que a idéia de Madison em separar a origem e a sobrevivência dos poderes servia ao propósito de que cada parte pudesse impor freios ao outro sem ameaçar sua própria existência. Assim, "separation in some respects serves to ensure interdependence - that is, checks - in others" (idem, p. 19). Tendo em vista a origem e a sobrevivência, a máxima separação seria característica do presidencialismo. Com respeito às ações o presidencialismo procura garantir a checagem mútua, redundando em sobreposição de poderes. Descartam outros critérios que não sejam os seguintes na definição do presidencialismo: eleição popular do Presidente; fixidez do prazo dos mandatos (não sendo possível sua alteração quando vigentes); o Presidente nomeia e compõe os quadros do Executivo (ministros, secretários etc.), e o Presidente tem alguma autoridade constitucional para produzir legislação.

Aparentemente essa perspectiva toma o rumo das proposições de Fischer e Jones, os quais apontam que existem corpos separados com poderes compartilhados. No entanto, Fischer salienta a diferença entre uma teoria de separação de poderes e uma teoria de freios e contrapesos. Se os três primeiros critérios de Shugart e Carey pertencem ao campo da separação de poderes do ponto de vista da existência do corpo, o último diz respeito ao poder de legislar, o qual pode ser compartilhado ou não. E, em termos estritos, o poder de legislar não diz respeito ao poder de checar. Como vimos, a própria concepção de Madison e Hamilton, se esclarecia o que era separação de poderes, não distinguia exatamente os poderes de ação e poderes de checagem.

Centrando sua análise no presidencialismo e seus tipos, Shugart e Carey analisam de maneira sistemática e comparada os poderes do Executivo. E os poderes do Legislativo? Se falamos de separação de poderes, se vamos considerar que ela é o cerne do presidencialismo, porque a ausência de análise sistemática dos poderes constitucionais do Legislativo, ou do Judiciário?

Lijphart (s/d), estabelecendo a comparação entre 36 democracias contemporâneas no intuito de identificar os tipos de democracia às quais pertencem (consensuais ou majoritárias), elege como uma das dimensões necessárias a relação Executivo-Legislativo. Considerando que no modelo de democracia majoritário existe a predominância do Executivo e no modelo consensual há um balanceamento entre um e outro poder, contrasta os sistemas presidencialistas e parlamentaristas. Selecionando de outros autores, como uma das diferenças entre os sistemas, o esquema da separação de poderes (idem, p. 136), o autor aponta que no sistema presidencial existe mútua independência e proibição de que os representantes participem do Executivo e do Legislativo ao mesmo tempo. No sistema parlamentarista o Executivo depende da confiança do Legislativo e seus membros podem participar do Executivo. Outra diferença é o direito de dissolução do Legislativo, direito que o Presidente não teria (mas aponta como exceções França e Israel). 
No entanto, não considera que a clivagem presidencialismo-parlamentarismo seja útil para esclarecer as relações entre Executivo e Legislativo, porque dentro desses sistemas existem muitos tipos de balanço do poder, alguns com predomínio do Executivo e outros com o do Legislativo. E extraindo a separação de poderes da própria definição de presidencialismo, comenta que a Suíça é um caso único de separação de poderes sem presidencialismo (idem, p. 139).

Para evidenciar os poderes do Executivo frente ao Legislativo, Lijphart enumera três fatores: 1) os poderes presidenciais definidos nas constituições; 2) a força e coesão dos partidos nas legislaturas; 3 ) a legitimidade do mandato derivado da eleição popular. Se o primeiro tem uma estabilidade considerável, os dois outros dependem das eleições. Por fim, define como indicador de dominância do Executivo sobre o Legislativo nos sistemas parlamentaristas a duração do gabinete. Interessam-nos dois pontos: 1) a separação de poderes não implica o presidencialismo, e 2) quais os poderes constitucionais do Presidente.

Se a separação de poderes não é exclusiva do presidencialismo, o inverso comprova-se: o presidencialismo implica separação de poderes. O problema levantado por Lijphart, que colide com a concepção de Shugart e Carey, é que a separação de poderes não é o melhor critério para definir o presidencialismo quando se busca diferenciá-lo de parlamentarismo. Contudo, dois de seus critérios de diferenciação (tipo de mandato - fixo ou dependente de outro poder - do cargo máximo executivo, e o modo de seleção do Executivo eleições ou outro poder) são diretamente relacionados à problemática da separação de poderes (idem, p. 128).

De maneira semelhante a Shugart e Carey, Lijphart também coloca ênfase em variáveis decorrentes do poder e da continuidade do Executivo. O Legislativo não é considerado da mesma forma. Não são resgatados seus poderes constitucionais $^{4}$. O Legislativo é traduzido em uma perspectiva reduzida, como o conjunto de forças partidárias, que apresentam coesão ou não,

\footnotetext{
4 A discussão sobre a organização do Legislativo e alguns de seus poderesédiscutida por Lijphartemumcapítuloseparado, deslocado da relação entre Executivo e Legislativo, e da separação de poderes (UIPHART, s/d, p. 214).
}

galvanizados em torno de interesses ou partidários ou particularistas. Algumas questões tratadas a partir do Executivo, como veto, muitas vezes tangenciam o problema da relação ExecutivoLegislativo como um problema de separação de poderes.

Peters (1997), comparando 17 democracias da Europa, apresenta um enfoque diferenciado. Para ele tanto no presidencialismo quanto no parlamentarismo a separação de poderes pode existir. Mede a difusão de poderes no parlamentarismo através da política eleitoral (campanha, escolha do Primeiro-Ministro), das mudanças institucionais (estabilidade do governo, capacidade do Executivo em formar ministérios, estruturas parlamentares, atividade legislativa), e, por fim, penetração do Primeiro-Ministro no Legislativo. Seu trabalho, apesar de não ser exaustivo no detalhamento dessas dimensões, e em conseqüência carecer de maiores evidências para comprovar padrões, tem o mérito de apontar que a questão da separação de poderes aplica-se aos casos em que existe o Estado moderno. Parece óbvio, e o é; contudo, é importante reiterá-lo.

Senão, vejamos. A teoria de Bagehot (1989, p. 14-20), acusando a fusão de poderes no parlamentarismo, baseia-se nos seguintes critérios: 1) origem do poder; 2 ) origem dos integrantes do corpo, e 3) capacidade de um poder dar fim ao mandato do outro. Nesse parlamentarismo, a origem do poder Executivo é o Legislativo, os integrantes do Legislativo podem pertencer ao Executivo e existe a capacidade de esse Executivo dissolver o Legislativo. Também há dimensões encobertas, não reveladas: anuncia que ou o Gabinete faz a lei e a executa ou pode dissolver a Câmara (idem, p. 20). A hipertrofia do Executivo significa que o Legislativo pode ser reduzido a um simples eleitor de gabinetes? Será que o Legislativo pode ser reduzido a somente escolher o Legislador? Ou Bagehot estava avisando que, para além da origem e da dissolução, havia um poder Executivo enfeixando todos os poderes, legislativos e executivos? A existência de hipertrofia absoluta do Executivo é que deve caracterizar o parlamentarismo? Ou apenas a chamada fusão de poderes?

Assim, revela-se que existem mais dimensões do que apenas constituir um corpo com poderes de dissolução sobre o outro para definir uma ausência de poderes separados, a ponto de acusarmos uma fusão de poderes. Peters vem defender 
justamente essa proposição.

\section{SEPARAÇÃO DE PODERES: UM MODELO PARA ANÁLISE}

$\mathrm{Na}$ seção anterior examinamos diferentes abordagens sobre a separação de poderes. Duas insuficiências podem ser anotadas: o foco no Executivo e a falta de clareza entre separação de poderes e capacidade de checagem e balanço. $\mathrm{O}$ foco no Executivo tem sua contrapartida no fato de que as dimensões constitucionais dos poderes dos legislativos e dos judiciários foram esmaecidas, sendo apresentadas por partes que serviam mais como elementos auxiliares à identificação dos poderes do Executivo. A falta de clareza entre separação de poderes e capacidade de checagem e balanço coloca-se quando um instrumento constitucional que é empregado como checagem é tratado rapidamente como um poder qualquer. Sim, certos instrumentos de checagem, talvez a maioria, podem ser tratados como um poder. Mas no que esse tratamento generoso ajuda o entendimento de como está arranjada a separação de poderes?

Tais insuficiências redundam em um exame não-sistemático da separação de poderes. Buscando suprir tais lacunas optamos por desenvolver uma análise da separação de poderes a partir do ponto de vista institucional. Dessa maneira, entendemos que o conhecimento dos dispositivos institucionais, particularmente delimitados pelos aspectos constitucionais e normatizadores da relação entre os poderes, permitirá evidenciar os limites estratégicos oferecidos à ação dos atores políticos.

Nosso ponto de partida para a formulação da análise é a proposição de Fischer: existem dois princípios, separação de poderes e sistema de checagem e balanço (FISCHER,1998, p. 60). Uma instituição não pode checar sem ter alguma medida de independência, e não pode ter independência sem poder checar. Aqui temos uma mudança: de poder separado para poder independente. Antes disso, Fischer havia afirmado a necessidade de que as partes deveriam ser separadas mas interdependentes, autônomas mas com reciprocidade no ato de governar (idem, p. 5). Afinal, aonde queremos chegar?

Queremos primeiramente introduzir maior clareza nessas considerações: poder separado, poder independente, poder de checar. O poder separado é aquele constituído como um corpo à parte, com origem e continuidade material próprias. Um poder independente detém prerrogativas de atuação sem a concorrência do outro poder. Essa repartição tripla não é novidade (ver CERQUEIRA, 1995, p. 127).

Definimos que um poder é independente quando suas prerrogativas são exclusivas, isto é, não são decididas em conjunto com outro poder. Decisão em conjunto significa que um outro poder pode alterar a decisão do primeiro, que não haverá decisão se ambos não cooperarem de alguma forma.

O poder de checar é a capacidade de um poder controlar o outro, suas atividades e decisões. Contudo, não pode substituir ou concorrer para decidir nas funções e prerrogativas assinaladas ao outro poder. Significa a capacidade de impedir a efetividade da decisão tomada ou avaliar e punir os efeitos das decisões tomadas e efetivadas, não de formular alternativas.

Precisamos esclarecer os níveis de decisão conjunta para evitar a possibilidade de confundir o poder de checar com a independência do poder. De maneira genérica, são eles:

1) quando um poder aprova ou rejeita a decisão do outro poder;

2) quando um poder aprova ou rejeita a decisão do outro poder e pode apresentar alternativa;

3) quando um poder aprova ou rejeita a decisão do outro poder e pode emendar;

4) quando um poder aprova ou rejeita a decisão do outro poder e pode emendar ou apresentar alternativa.

Só no primeiro se confunde com checagem, isto é, no qual um poder decide o conteúdo conforme suas atribuições e ao outro poder só resta impedir. Os restantes consideramos como aqueles em que ambos os poderes tomam decisões conjuntas por excelência. É claro que pode ser contraposto que informalmente pode haver consultas, trade offs e negociações variadas entre os poderes, gerando praticamente uma decisão conjunta. Salientamos, no entanto, que estamos preocupados com a institucionalidade da relação entre os poderes, basicamente a partir das disposições constitucionais e das normas legais que organizam essa relação. 
Precisamos agora determinar o balanço entre independência e checagem. A lógica normativa, tendo em vista a teoria da separação de poderes, é que quanto mais um poder decidir unilateralmente, sem concorrência de outro, maior devem ser os instrumentos de checagem. E quanto mais decisões conjuntas, menor a necessidade de checagens. O equilíbrio entre checagem e independência então apresenta-se como uma relação direta e linear ${ }^{5}$, buscando criar o ambiente de corpos separados mas com poderes compartilhados.

Temos então as seguintes situações de desequilíbrio ${ }^{6}$ :

1) quando existe baixa independência e alta checagem, um poder provoca a paralisia decisória e diminui a possibilidade de implementação da agenda política do outro;

2) quando existe alta independência e baixa checagem, significa que um poder tem a possibilidade de predomínio, subordinando o outro à sua agenda.

As situações de desequilíbrio concorrem para a não-efetivação dos princípios fundadores da moderna separação de poderes (contenção recí- proca dos poderes para evitar abusos, tendo em vista a liberdade e o bom governo).

As situações de equilíbrio são quando temos:

1. checagem baixa e independência baixa, em que a maior parte das decisões são tomadas em conjunto; a checagem sendo baixa, compensa a não-independência existente. A agenda torna-se compartilhada;

2. checagem alta e independência alta; mesmo que um poder tenha alto poder de decisão, o outro pode estabelecer controles e punições sobre essas decisões. Dessa maneira, diminui o campo de atuação livre do outro poder, forçando a adequação da agenda política aos movimentos do primeiro poder.

Essas situações de equilíbrio-desequilíbrio podem ser empregadas no balanço entre os poderes. Ressaltamos que em situações nos quais exista grave polarização político-ideológica entre Executivo, Legislativo e Judiciário o arcabouço das regras pode vir a propiciar ou incrementar resultados que redundem em instabilidade política. O Quadro I ajuda-nos a visualizar melhor a proposição:

QUADRO I - Balanço entre poderes e seus efeitos

\begin{tabular}{|c|c|c|c|c|c|}
\hline & \multicolumn{2}{|c|}{ Poder A } & \multicolumn{2}{c|}{ Poder B } & Pior efeito possível* $^{*}$ \\
\hline \multirow{3}{*}{ Equilíbrio } & Independência & Checagem & Independência & Checagem & \\
\cline { 2 - 6 } & ALTO & ALTO & ALTO & ALTO & \\
\cline { 2 - 6 } & BAIXO & BAIXO & BAIXO & BAIXO & \\
\cline { 2 - 6 } Quase equilíbrio & ALTO & BAIXO & BAIXO & ALTO & \\
\hline \multirow{5}{*}{ Desequilíbrio } & BAIXO & ALTO & BAIXO & ALTO & Paralisia de ambos \\
\cline { 2 - 7 } & ALTO & ALTO & ALTO & BAIXO & Predomínio do poder A \\
\cline { 2 - 7 } & ALTO & ALTO & BAIXO & BAIXO & Predomínio do poder A \\
\cline { 2 - 6 } & BAIXO & ALTO & BAIXO & BAIXO & Paralisia de B \\
\cline { 2 - 6 } & ALTO & ALTO & BAIXO & ALTO & Paralisia de B \\
\cline { 2 - 7 } & ALTO & BAIXO & ALTO & BAIXO & Conflito \\
\hline
\end{tabular}

* Pior efeito da situação institucional

\footnotetext{
5 Existe um ponto de confusão ou superposição: se um poderé independente porque pode decidir semprecisar do outro poder para efetivá-las, e se checagemé a capacidade de umimpedir ao outro, esse impedimento não seriajá um elemento de não-independência?Sim, de maneira genénica. Por isso, quanto mais checagemmais recuaa independência genérica, mas não aindependência pemitida pelas regras. $\mathrm{O}$ equilibrio propostoé que caso essaindependência pemitida
}

pelas regras seja baixa, a necessidade de checagens diminui, mantendo, de certa forma, a mesmaindependênciagenérica.

6 Podemoscriartambémumsetormédiona escala Acontece que a relação desse setor médio comos setores alto e baixo é o mesmo que o setor alto como setor baixo e vice-versa, porém com intensidade menor. Dessa forma, nessa parte inicial optamos, para efeitos de maior clareza e contraste, trabalhar com situações extremas. 
Uma palavra deve ser dada sobre os poderes. Existem três planos de poderes que estão disponíveis para o Legislativo e o Executivo. O primeiro é o plano do que é permitido fazer quanto às políticas públicas, as atribuições; o segundo diz respeito aos instrumentos institucionais que permitem aprovar e implementar aquelas políticas, tanto em relação a si próprios quanto em relação aos outros poderes. Fazem parte desses poderes a capacidade de formar a agenda, e a capacidade de iniciar e decidir sobre a legislação, atos executivos e adjucativos. O caso do Judiciário é mais específico. Sua força é seu mandato permanente, aliado a um alto poder de checar as decisões de outros poderes. Foi considerado o poder mais fraco por Montesquieu e Madison, na medida em que não decide propriamente políticas novas. Neste estudo, no entanto, centramos nossas atenções na relação Executivo-Legislativo .

O terceiro conjunto são os poderes de checagem, aqueles poderes que permitem a um poder obstaculizar as ações e decisões do outro: vetos, julgamentos de ações, investigações, sessões de informações etc.

Esse quadro não incorpora as dimensões do sistema eleitoral e do sistema partidário, tais como, por exemplo, o quadro de forças existente dentro do Legislativo, as coalizões, a coesão partidária, nem a formação ministerial. A incorporação desses elementos tornaria a análise sobre a real separação de poderes mais completa. No entanto, estamos circunscritos aos aspectos constitucionais desejando com isso garantir, tendo em vista nossos recursos imediatos, maior precisão e confiabilidade na análise.

Identificamos dois problemas nas análises sobre a separação de poderes: a ênfase nos poderes presidenciais e ausência de clareza sobre a caracterização dos elementos constitucionais de separação, independência e checagem de poderes. A solução do primeiro passa por identificarmos os poderes do Legislativo e do Judiciário; e a do segundo o mesmo em relação aos instrumentos que se enquadram naquelas classificações.

No entanto, a enumeração desses poderes de maneira genérica e abstrata revela-se prematura na medida em que a diversidade de instrumentos institucionais existentes no mundo real é considerável. E não apenas no mundo real, mas também na possibilidade teórica de que novos meios e mecanismos possam ser empregados para realizar o balanço entre os poderes. O número desses meios é muito alto ${ }^{7}$. Dessa maneira, a melhor forma de enfrentar esse desafio é propor um exercício exploratório. Focalizando nossa atenção nos regimes presidencialistas, tendo em vista que nesses sistemas necessariamente encontramos separação de poderes, a análise comparada impõese.

\section{ASPECTOS METODOLÓGICOS}

Esperamos um resultado ao sermos capazes de identificar as prerrogativas de todos os poderes e os instrumentos de independência e checagem: verificar se as proposições teóricas da separação de poderes estão presentes nos arranjos institucionais daqueles regimes. De modo mais específico: a separação de poderes existente garante o balanço de poder, de maneira a não permitir a dominação de um poder sobre o outro? Assim, quanto mais desequilíbrio institucional existir maior a chance de ou um poder ter predominância em relação ao outro ou existir paralisia decisória. E o desequilíbrio institucional é maior quanto maior for a distância entre independência e checagem. Essa distância, por sua vez, cresce à medida em que ou independência é maior que checagem, ou checagem é maior que independência

Nosso objeto de estudo é formado pelos casos de regimes presidenciais da América Latina: Argentina, Bolívia, Brasil, Chile, Colômbia, Costa Rica, El Salvador, Equador, Guatemala, Haiti, México, Nicarágua, Panamá, Paraguai, Peru, República Dominicana, Uruguai e Venezuela. Duas observações são necessárias: 1) Cuba ficou excluída devido à natureza diferenciada do seu sistema econômico e político (não é capitalista e nem apresenta um sistema representativo acoplado a uma democracia de feição clássica), e 2) o caso peruano é controverso na medida em que fortes fatores externos ao jogo entre poderes tornam o seu estatuto constitucional algo precário; mesmo assim, quando o bloco de poder dissolve-se como aconteceu com Fujimori, o mecanismo constitucional volta a operar. A principal característica desses países é que são presidencialistas. Existe, no entanto, ampla diversidade sócio-econômica entre eles. As regiões apresentam diferenciações

\footnotetext{
7 Ver por exemplo a possibilidade e existência de veto Legislativo emKorn (1996).
} 
históricas de ocupação e constituição social, política e econômica.

Analisamos basicamente as Constituições. São elas: argentina com reformas de 1994; boliviana de 1967 com reformas de 1994; brasileira de 1988 com reformas até 1997; chilena de 1980 com reformas de 1997; colombiana de 1991 com reformas de 1997; costarriquenha de 1949 com reformas até 1997; dominicana de 1994; salvadorenha de 1982; guatemalteca com reformas de 1993; haitiana de 1987; mexicana de 1917 com reformas até 1998; nicaragüense de 1987; panamenha de 1972 com reformas de 1983 e 1994; paraguaia de 1992; peruana de 1993; uruguaia de 1967 com reformas de 1989, 1994 e 1997; venezuelana de 1961 com reformas de 1983.

Temos ao todo 18 casos, com um número de variáveis bastante alto. A partir dos conceitos de separação, independência e checagem de poderes, criamos três variáveis de mesmo nome que compreendem, por sua vez, outras tantas variáveis, as quais chamarei de subvariáveis de nível 1 , e de nivel 2 (geralmente formadas por subvariáveis de nível 1). Dessa forma, as três variáveis correspondentes a esses conceitos são variáveis que se agregam a um conjunto maior de outras variáveis.

A variável separação ${ }^{8}$ inclui como subvariáveis de nivel 2: 1) origem do poder, 2) independência do mandato, 3) independência financeira do poder ${ }^{9}, 4$ ) forma de fiscalização das contas, e 5) atribuições constitucionais exclusivas. Por sua vez, algumas dessas variáveis são agregados de outras, formando o que chamo de subvariáveis de nivel 1: a fiscalização das contas é formada por seis outras variáveis (origem do corpo fiscalizatório, origem dos dirigentes, vinculação administrativa, independência do mandato e âmbito de ação); as atribuições constitucionais exclusivas são compostas por três

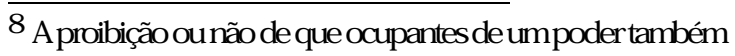
ocupem cargos emoutro poderé uma variável importante. Contudo não houve razão para computá-la na medida em que todas as constituições apontaram a proibição desse acúmulo.

9 Tentamos incluir a variável "quemdecide a remuneração dos ocupantes dos cargos máximos dos poderes”, contudo grande parte das constituições não dispõe desse dado para todosos poderes.
}

variáveis denominadas atribuições constitucionais exclusivas: a) executivas, b) legislativas, e c) judiciárias.

A variável independência decisional dos poderes é formada por sete subvariáveis de nivel 2: 1) iniciativa de lei dos poderes, 2) quorum legislativo para tomada de decisões, 3) recursos de tempo (sessões extraordinárias e urgência), 4) urgência do Executivo, 5) decreto executivo e delegação, 6) decreto de estado de sítio, 7) poder de convocação de consultas nacionais. Novamente, algumas dessas subvariáveis são agregados de outras subvariáveis, dessa vez de nível 1. A subvariável "iniciativa de lei dos poderes" compreende as seguintes subvariáveis: 1) iniciativas de leis constitucionais, de leis orçamentárias e leis ordinárias, por poder, e 2) quorum legislativo para decisões, que por sua vez se subdivide em quorum para emendas constitucionais, leis orçamentárias e leis ordinárias. A subvariável de nível 2 "recursos de tempo" compreende as subvariáveis: 1) poder de solicitar urgência a projetos e 2) poder de convocar sessões extraordinárias, por poder. Já a subvariável "poder de urgência do Executivo" abarca: 1) procedimentos no caso de o Legislativo não atender a pedido no tempo constitucional; 2) momento do pedido de urgência; 3) limitação do número de projetos com pedido de urgência; 4) possibilidade de o pedido de urgência ser derrubado, e 5) quorum para proceder a derrubada. A subvariável "decreto do Executivo e delegação" é composta por: 1) controle de vigência do decreto do poder Legislativo; 2) área de atuação do decreto; 3) poder de reedição do decreto, e 4) existência e amplitude da lei delegada. E, ainda, a subvariável "decreto de estado de sítio" compreende: 1) quem pode decretar e 2) qual a decisão que cabe ao outro poder. A subvariável "convocação de consultas nacionais" inclui: 1) quem tem poder de convocar e 2) qual a limitação do tema de convocação.

A variável checagem dos poderes é composta pelas seguintes subvariáveis de nivel 2:1) poderes de checagem do Executivo, 2) poderes de checagem da Câmara baixa, e 3) poderes de checagem da Câmara alta. A subvariável de nível 2 "poderes de checagem do Executivo" é composta pelas subvariáveis de nivel 1:1) existência do poder de veto, 2) existência de veto total; 3) existência de veto parcial; 4) quorum do Legislativo para derrubar o veto; 5) existência de veto a matéria constitucional; 6) tipo de participação das câmaras para decidir sobre o veto; 7) forma de exame do 
veto pelo Legislativo; 8) procedimento para trâmite do veto sem apreciação dentro do tempo constitucional pelas câmaras; 9) trâmite das partes não vetadas do projeto de lei; 10) poder do Executivo em dissolver o Legislativo, e 11) participação ministerial em sessões legislativas.

As subvariáveis de nível 2 "poderes de checagem da Câmara alta" e "poderes de checagem da Câmara baixa" compreendem as seguintes subvariáveis de nível 1:1) existência de comissão investigatória exclusiva; 2) possibilidade de pedidos e convocação de sessão de informações sobre outro poder; 3) poder de apreciação de contas; 4) poder de abertura de processo para julgamento; 5) possibilidade de conceder autorização para preenchimento de cargos; 6 ) obrigatoriedade de receber comunicação de planos governamentais; 7) capacidade de expedição de autorização sobre matérias diversas, como guerra-paz, autorização de viagens etc.; 8) capacidade de expedição de voto de censura ou confiança sobre o Presidente; 9) capacidade de expedição de voto de censura ou confiança sobre ministros e equipe presidencial; 10) capacidade de solicitar a demissão do Presidente; 11) capacidade de proceder ao julgamento das contas de outros poderes; 12) capacidade de julgar o Presidente; 13) capacidade de julgar ministros e equipe presidencial, e 14) capacidade de impedir atos inconstitucionais do Executivo.

Dois passos importantes foram tomados: em primeiro lugar, elaboramos as escalas dos indicadores, que variam de 0 a infinito, dependendo do número de opções existentes. Em segundo lugar normalizamos os valores obtidos dentro de uma escala percentual de 0 a 100 . As escalas dos indicadores das variáveis de separação e independência, e suas subvariáveis, foram construídas de maneira a variar no sentido do menos separado ao mais separado. Valores maiores, portanto, significam maior separação e independência. Os indicadores de checagem dos poderes, apesar de serem em sua maioria constituídos por valores dicotômicos de presença ou ausência, também foram pontuados de maneira a serem somados e gerarem um resultado que também é intuitivo: quanto mais alto é o valor da soma, maior é o poder de checagem do poder.

A agregação dos valores nas variáveis superiores (separação, independência, checagem) exigiu sua normalização tendo em vista alcançar comparabilidade. As escalas variando do menor ao maior, numericamente, permitiram estabelecermos os patamares mínimo e máximo de sua variação. Esses valores serviram de base para a normalização de dados que fizemos, surgindo uma segunda escala, variando de 0 a 100. Assim, todas as variáveis de nível 2 foram normalizadas dentro dessa segunda escala, possibilitando sua comparação interna. Além disso, demos peso para algumas variáveis tendo em vista sua importância. Assim, as subvariáveis de nível 2 "recursos de tempo" e "urgência do Executivo" foram multiplicadas pelo fator $1 / 2$ enquanto a subvariável "convocação de consultas nacionais" foi multiplicada pelo fator $1 / 3$, provocando uma diminuição de seu peso no cômputo geral. Essa decisão é arbitrária mas guarda relevância, na medida em que os elementos constituintes dessas subvariáveis não são cruciais para a relação entre Executivo e Legislativo, ainda que exerçam razoável efeito. A ausência de um padrão teórico claro de máximo e mínimo de separação de poderes e poder de checagem levou-nos a essa decisão; dessa maneira, superamos essa ausência.

Posteriormente as subvariáveis de nível 2 foram somadas e novamente sofreram um processo de normalização tendo em vista os valores máximos e mínimos possíveis. Dessa forma as três variáveis finais (separação, independência e checagem) apresentam resultados comparáveis, que variam de 0 a 100 para toda e qualquer uma delas.

Essa padronização permitiu-nos ter maior visibilidade quanto à identificação do equilíbrio entre a independência dos poderes e os poderes de checagem por país. Se todas as variáveis têm como limites 0 e 100 , então pode-se esperar, tendo em vista o esperado equilíbrio, que quando a independência tenha, por exemplo, o valor 40 , então a checagem também o apresente ${ }^{10}$. Dessa maneira está garantida a identificação do caráter linear e positivo previsto pela teoria.

\section{OS RESULTADOS}

Nesta seção vamos analisar, em primeiro lugar, a separação de poderes nos países anteriormente

\footnotetext{
10 Umsegundo momento de investigaçãoérequerido. Tratase de alinhar lado a lado o poder da função e seu correspondente mecanismo de checagem
} 
definidos desde um ponto de vista sistêmico, isto é, apresentando suas características como um sistema único, mostrando os resultados gerais para cada variável. Posteriormente vamos proceder à comparação entre elas, estabelecendo as diferenças e semelhanças entre os formatos constitucionais.
A Tabela 1 mostra-nos o comportamento das variáveis separação, independência e checagem conforme cada país. Apesar de a maior parte dos países situarem-se em um patamar médio, existem oscilações importantes.

TABELA 1 - Separação, independência e checagem em \%, por país latino-americano presidencialista

\begin{tabular}{|c|c|c|c|}
\hline País & Separação & Independência & Checagem \\
\hline Argentina & 52,2 & 47,9 & 46,2 \\
\hline Bolívia & 71,2 & 36,7 & 28,7 \\
\hline Brasil & 68,9 & 61,2 & 49,5 \\
\hline Chile & 71,4 & 59,7 & 36,1 \\
\hline Colômbia & 57,8 & 45,1 & 43,7 \\
\hline Costa Rica* & 46,7 & 24,0 & 46,2 \\
\hline El Salvador* & 59,3 & 13,6 & 50,4 \\
\hline Equador $^{*}$ & 61,1 & 32,8 & 44,9 \\
\hline Guatemala & 65,8 & 29,5 & 47,6 \\
\hline Haiti & 48,6 & 41,4 & 40,3 \\
\hline México & 45,6 & 15,7 & 47,9 \\
\hline Nicarágua* & 63,1 & 39,2 & 26,7 \\
\hline Panamá $^{*}$ & 53,7 & 18,5 & 49,5 \\
\hline Paraguai $^{*}$ Peru* & 63,1 & 37,8 & 45,8 \\
\hline Rep. Dominicana $^{*}$ & 57,4 & 41,3 & 51,5 \\
\hline Uruguai & 59,2 & 28,2 & 47,4 \\
\hline Venezuela & 43,3 & 53,0 & 55,5 \\
\hline
\end{tabular}

* Países com apenas uma câmara legislativa.

Três países apresentam forte separação entre os poderes: Bolívia, Chile e Brasil, acima dos $66 \%$, seguidos pela Guatemala. As menores separações pertencem a Uruguai, México e Costa Rica.

Brasil e Chile têm os maiores valores de independência, seguidos de Uruguai, Argentina e Colômbia. A menor independência é apresentada por El Salvador, seguido por México e Panamá. Também Costa Rica e República Dominicana situam-se em patamares de independência abaixo dos $33 \%$. Nenhum país apresenta uma indepen- dência acima dos $60 \%$.

Os resultados relativos à checagem têm menor variação interna. Uruguai, Peru, El Salvador e Venezuela são os que, na ordem, apresentam maior percentual de checagem, pouco ultrapassando os $50 \%$. O Brasil quase alcança esse grupo. Os menores percentuais pertencem a Nicarágua e Bolívia. A Tabela 2 oferece-nos uma medida menos extensa ao agrupar por níveis de percentuais; no entanto, é útil porque permite identificarmos os casos mais extremos.

TABELA 2 - Separação, independência e checagem por níveis de percentuais* por país latino-americano presidencialista

\begin{tabular}{|c|c|c|c|}
\hline Nível & Separação & Independência & Checagem \\
\hline Alto & Bolívia, Brasil, Chile & & \\
\hline Médio & Todos os países restantes & Todos os países restantes & $\begin{array}{c}\text { Todos os países } \\
\text { restantes }\end{array}$ \\
\hline
\end{tabular}




\begin{tabular}{|c|c|c|c|}
\hline Baixo & $\begin{array}{c}\text { Costa Rica, El Salvador, Equador, } \\
\text { Guatemala, México, Panamá, Rep. } \\
\text { Dominicana }\end{array}$ & Bolívia, Nicarágua \\
\hline
\end{tabular}

${ }^{*}$ Baixo $=0 \%$ a $33 \%$; Médio $=33,1 \%$ a $66 \%$; Alto $=66,1 \%$ a $100 \%$.

No conjunto a institucionalidade relativa à separação de poderes é majoritariamente média, isto é, a maioria dos países apresenta um conjunto de regras de separação física de poderes que afinal não separa tão fortemente. As exceções são Bolívia, Brasil e Chile, os quais apresentam poderes altamente separados. Já no campo da independência dos poderes há uma cisão: 38,9\% dos países têm um baixo instrumental constitucional que garanta a independência decisional dos poderes Executivo e Legislativo. Dessa forma, praticamente $60 \%$ dos países estão situados em um patamar médio. Já a checagem entre os poderes também situa-se em patamar médio, apresentando somente duas exceções, Bolívia e Nicarágua, pouco desenvolvidas constitucionalmente no aparato de checagem.

Considerando que deve haver um equilíbrio entre a participação de mecanismos de independência dos poderes e de mecanismos de checagem temos no Gráfico 1 uma medida mais refinada, a combinação entre as variáveis independência e checagem (a linha reta representa os pontos de equilíbrio, quando para um valor percentual de independência existe um igual valor percentual para checagem). Esse gráfico mostra-nos mais claramente que países como El Salvador, México e Panamá estão apresentando maior participação de mecanismos de checagem frente aos mecanismos de independência de poderes. Ao contrário, Chile, Brasil e Nicarágua apresentam uma maior participação da independência frente aos mecanismos de checagem. Quatro países tendem ao equilíbrio entre independência e checagem: Haiti, Colômbia, Argentina e Uruguai, os três primeiros com leve ênfase no campo da independência e o último no campo da checagem.

GRÁFICO 1 - Independência e checagem; países presidencialistas da América Latina (em \%)

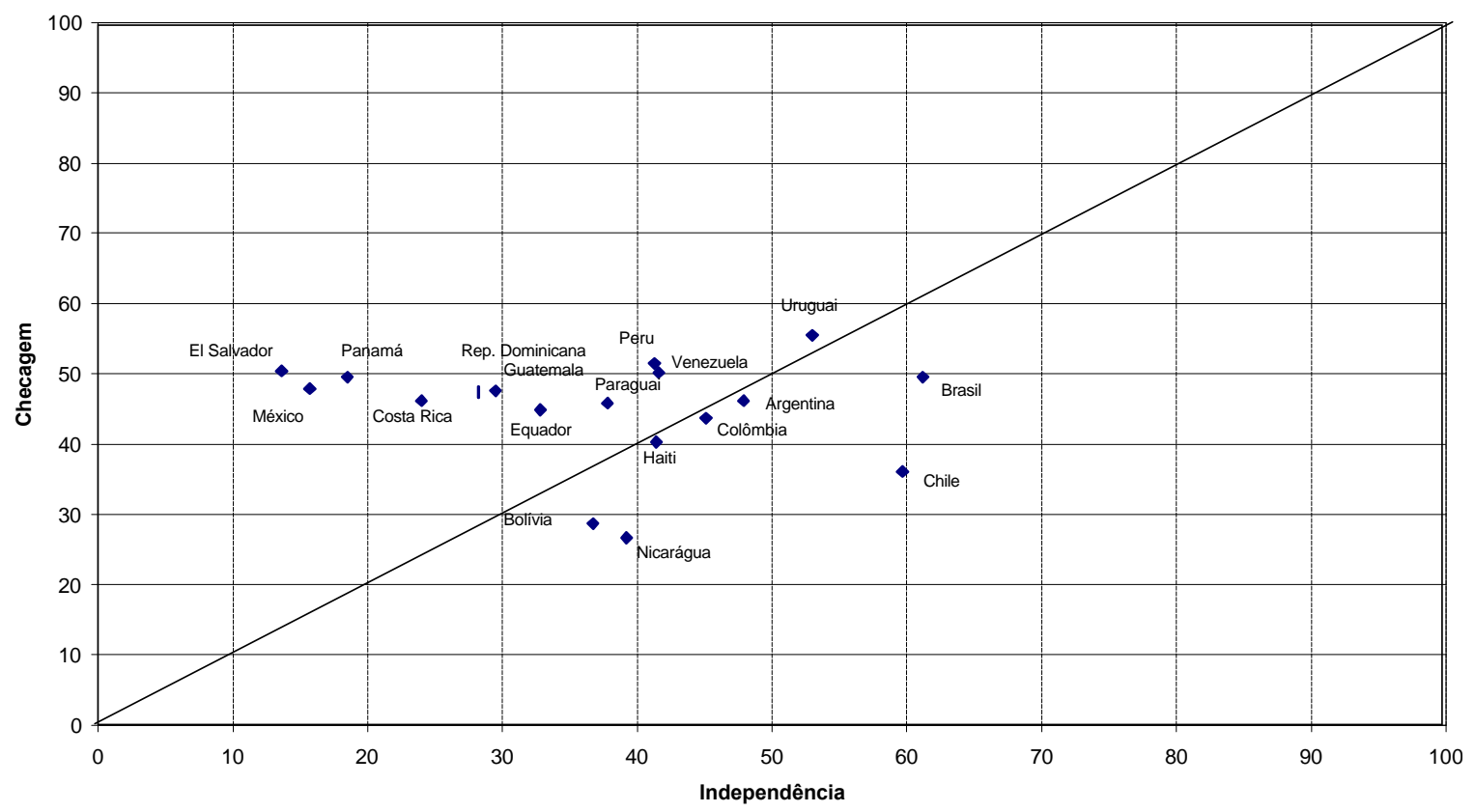

A seguir vamos examinar o comportamento das variáveis independência e checagem de poderes relativas a cada poder, buscando demonstrar o padrão existente e verificando se as premissas da teoria da separação de poderes são confirmadas.
Abaixo temos o balanço de poder entre o Executivo e o Legislativo para os casos em análise. A Tabela 3 apresenta a combinação das variáveis independência e checagem objetivando estabelecer o padrão de desequilíbrio. 
Tabela 3 - Independência do Executivo e checagem do Legislativo em \% por país latino-americano presidencialista

\begin{tabular}{|c|c|c|c|}
\hline País & $\begin{array}{c}\text { Executivo } \\
\text { Independência }\end{array}$ & $\begin{array}{c}\text { Legislativo } \\
\text { Checagem }\end{array}$ & Distância \\
\hline Argentina & 60,4 & 48,1 & 12,3 \\
\hline Bolívia & 52,9 & 25,9 & 27,0 \\
\hline Brasil & 81,5 & 51,9 & 29,6 \\
\hline Chile & 78,5 & 40,7 & 37,8 \\
\hline Colômbia & 75,9 & 44,4 & 31,5 \\
\hline Costa Rica* $^{*}$ & 30,5 & 48,1 & $-17,6$ \\
\hline El Salvador* & 30,5 & 40,7 & $-10,2$ \\
\hline Equador* & 57,9 & 37,0 & 20,9 \\
\hline Guatemala & 45,6 & 48,1 & $-2,5$ \\
\hline Haiti & 45,7 & 59,3 & $-13,6$ \\
\hline México & 35,7 & 44,4 & $-8,7$ \\
\hline Nicarágua* & 47,0 & 14,8 & 32,2 \\
\hline Panamá* & 35,2 & 51,9 & $-16,7$ \\
\hline Paraguai & 62,4 & 44,4 & 18,0 \\
\hline Peru* & 61,8 & 63,0 & $-1,2$ \\
\hline Rep. Dominicana & 32,6 & 51,9 & $-19,3$ \\
\hline Uruguai & 60,9 & 66,7 & $-5,8$ \\
\hline Venezuela & 39,2 & 51,9 & $-12,7$ \\
\hline
\end{tabular}

* Países com apenas uma câmara legislativa.

Brasil, Chile e Colômbia são os países que têm o maior percentual (acima de 70\%) de independência do Executivo, seguidos de Argentina, Paraguai, Peru e Uruguai (de 60 a 70\%). Os menores percentuais pertencem a Costa Rica, El Salvador, República Dominicana, México e Venezuela, situados entre 30 e $40 \%$.

Quanto à checagem do Legislativo temos Uruguai e Peru como aqueles ultrapassam a barreira dos $60 \%$, seguidos do Haiti, com $59,3 \%$. Nicarágua $(14,8 \%)$ e Bolívia $(25,9 \%)$ são aqueles que têm menor percentual relativo à existência de poderes de checagem.

As maiores distâncias entre a independência do Executivo e a checagem do Legislativo estão no Chile, Nicarágua e Colômbia, a favor da independência do Executivo, e Costa Rica e República Dominicana a favor da checagem do Legislativo .

$\mathrm{Na}$ Tabela 4 temos os resultados da independência do Legislativo frente à checagem do respectivo Executivo, estabelecendo também a distância de pontos percentuais entre um e outro.

TABELA 4 - Independência do Legislativo e checagem do Executivo em \% por país latino-americano presidencialista

\begin{tabular}{|c|c|c|c|}
\hline País & $\begin{array}{c}\text { Legislativo } \\
\text { Independência }\end{array}$ & $\begin{array}{c}\text { Executivo } \\
\text { Checagem }\end{array}$ & Distância \\
\hline Argentina & 70,4 & 44,3 & 26,1 \\
\hline Bolívia & 63,0 & 31,4 & 31,6 \\
\hline Brasil & 72,1 & 47,1 & 25,0 \\
\hline Chile & 58,4 & 31,4 & 27,0 \\
\hline Colômbia & 50,1 & 42,9 & 7,2 \\
\hline Costa Rica* & 39,2 & 44,3 & $-5,1$ \\
\hline
\end{tabular}




\begin{tabular}{|c|c|c|c|}
\hline El Salvador $^{*}$ & 39,2 & 60,0 & $-20,8$ \\
\hline Equador $^{*}$ & 60,5 & 52,9 & 7,6 \\
\hline Guatemala & 70,4 & 47,1 & 23,3 \\
\hline Haiti & 50,5 & 21,4 & 29,1 \\
\hline México & 27,9 & 51,4 & $-23,5$ \\
\hline Nicarágua $^{*}$ & 54,6 & 38,6 & 16,0 \\
\hline Panamá $^{*}$ & 40,0 & 47,1 & $-7,1$ \\
\hline Paraguai $^{\text {Peru* }}$ & 48,0 & 47,1 & 0,9 \\
\hline Rep. Dominicana & 55,1 & 40,0 & 15,1 \\
\hline Uruguai & 49,2 & 42,9 & 6,3 \\
\hline Venezuela & 70,4 & 44,3 & 26,1 \\
\hline
\end{tabular}

* Países com apenas uma câmara legislativa.

Em relação à independência do Legislativo, Venezuela, Brasil, Argentina e Uruguai ultrapassam a barreira dos $70 \%$. Os menores percentuais são do México, seguido de Costa Rica e El Salvador. Em relação à checagem do Executivo o maior percentual é de El Salvador, seguido de Equador e México. Quanto aos menores percentuais temos Bolívia e Chile, ambos com 31,4\%.

A maior distância entre independência do Legislativo frente à checagem do Executivo, a favor do primeiro, é da Bolívia, seguido do Haiti. Imediatamente temos Venezuela, Chile, Uruguai, Argentina, Brasil e Guatemala, todos na faixa de entre 20 e 30 pontos percentuais. A maior distância a favor da checagem do Executivo é do México, seguido de El Salvador.

O Gráfico 2 mostra-nos a relação entre a independência do Executivo e a checagem do Legislativo. Quanto mais próximo da reta entre os pontos $(0,0)$ e $(100,100)$ mais equilíbrio existe no balanço entre os poderes. Próximos dessa linha de equilíbrio, com leve ênfase para a checagem do Legislativo, temos o Peru, Guatemala e Uruguai. No campo da predominância da independência do Executivo temos a Argentina, seguida do Paraguai, como aqueles que mais se aproximam da reta. No entanto, se comparados com o bloco antes mencionado, estão mais distantes da reta e entre si.

GRÁFICO 2 - Independência do Executivo e checagem do Legislativo; países presidencialistas da América Latina (em \%)

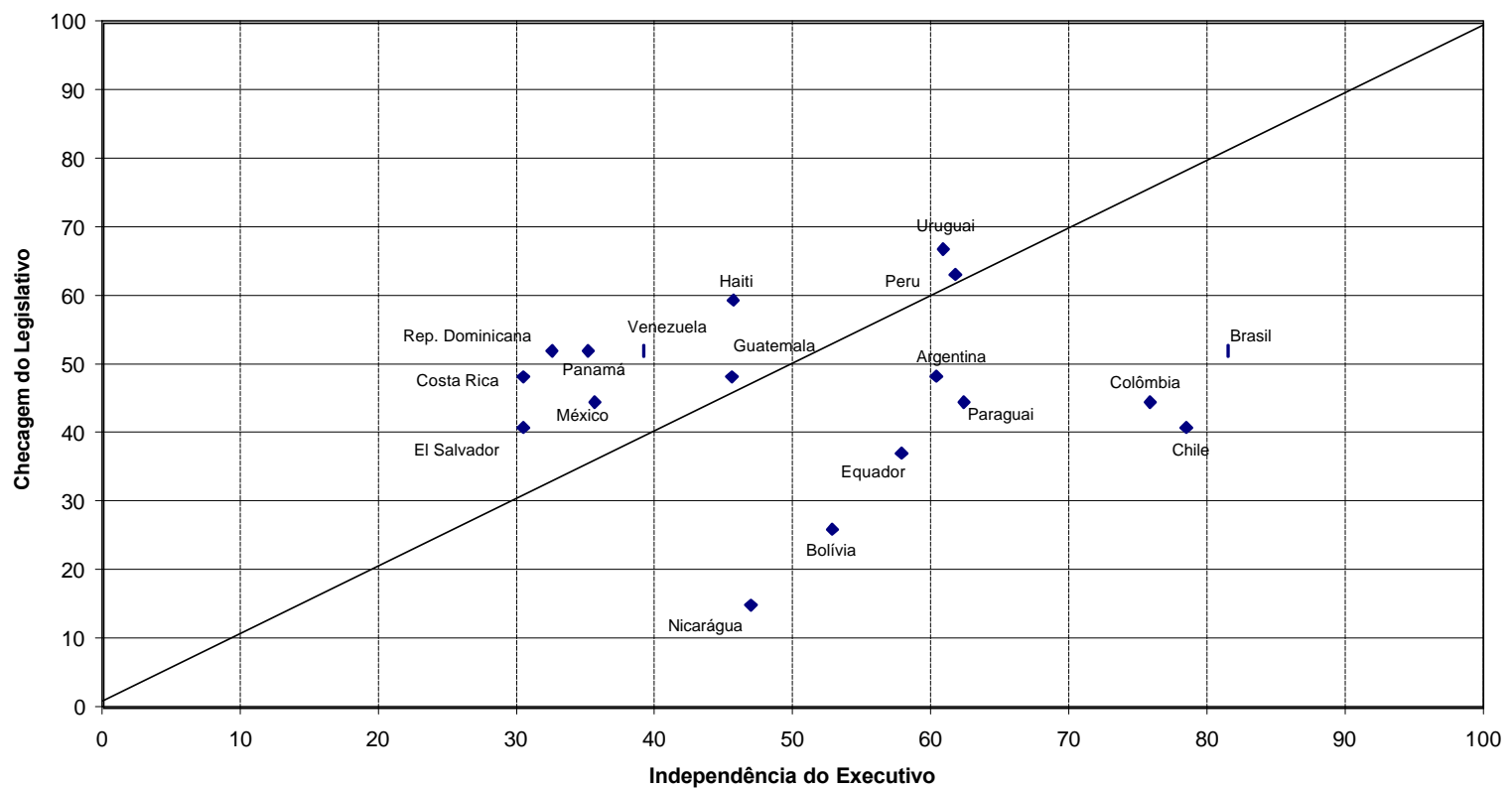


GRÁFICO 2 - Independência do Executivo e checagem do Legislativo; países presidencialistas da América Latina (em \%)

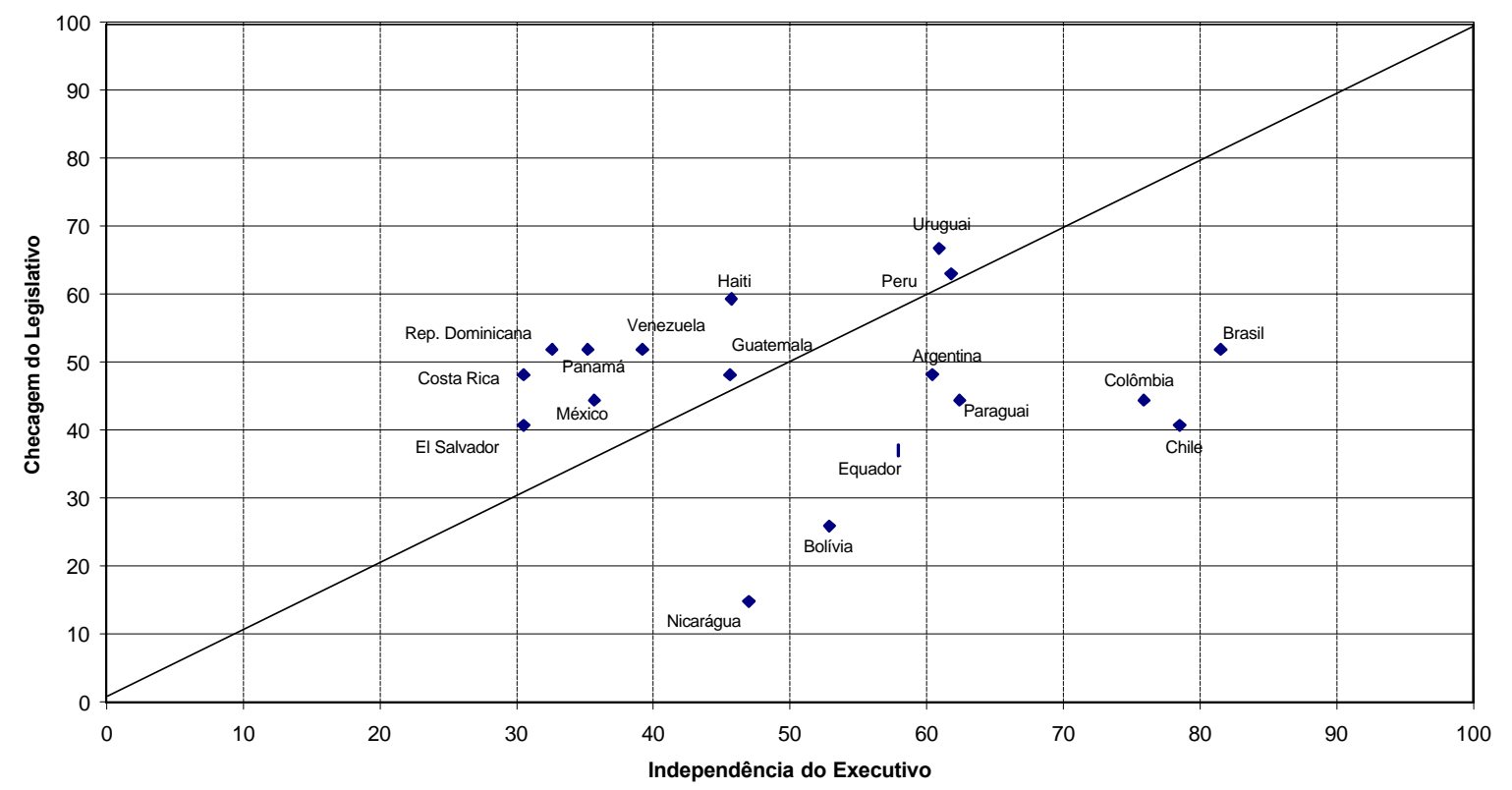

Os países que apresentam significativa distância da reta, com maior ênfase na checagem do Legislativo, são República Dominicana, Panamá, Costa Rica, seguidos de Haiti e Venezuela. Do lado dos países que mostram maior independência do Executivo temos Chile, Brasil, Colômbia e Nicarágua. Nitidamente o bloco de países acima da reta é menos disperso e menos distante da mesma do que o bloco de países abaixo dela. Isso significa que os países que apresentam maior checagem do Legislativo estão, no conjunto, mais equilibrados.
Já no Gráfico 3 temos que a Costa Rica aproxima-se mais do equilíbrio no campo daqueles países que apresentam uma checagem do Executivo maior que a independência do Legislativo. No campo dos países que apresentam maior independência do Legislativo temos o Paraguai como o mais equilibrado. Nesse grupo temos um conjunto significativo de países com uma grande distância em relação à reta de equilíbrio: Venezuela, Bolívia, Argentina, Uruguai e Brasil, seguidos de Guatemala, Chile e Haiti.

Gráfico 3 - Independência do Legislativo e checagem do Executivo; países presidencialistas da América Latina (em \%)

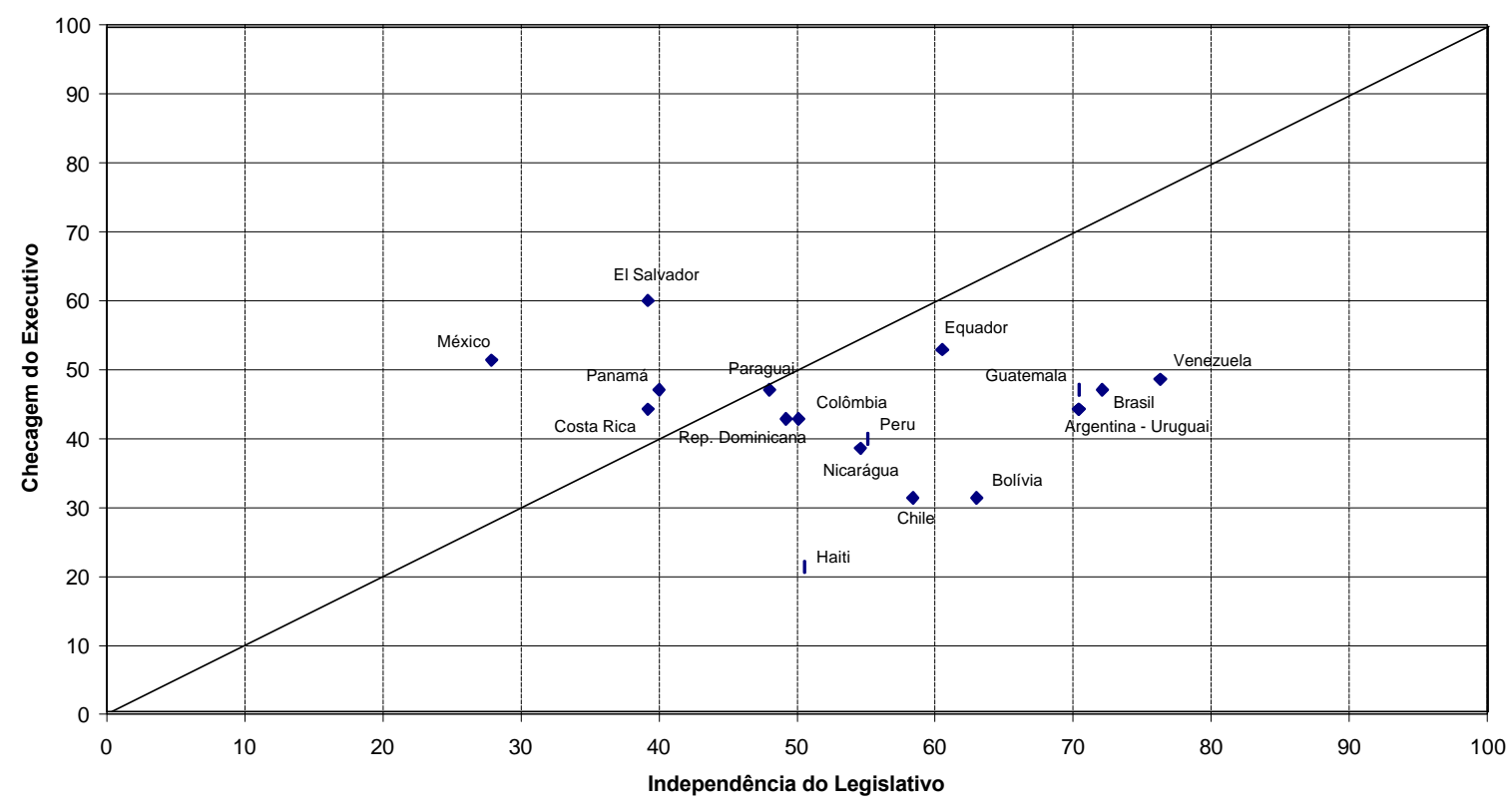


Contudo, uma análise mais completa exige que independência e checagem de cada poder. coloquemos lado a lado essas duas dimensões:

TABELA 5 - Situação da independência e da checagem dos poderes Executivo e Legislativo por país latino-americano presidencialista

\begin{tabular}{|c|c|c|c|}
\hline País & $\begin{array}{c}\text { Legislativo } \\
\text { Independência }\end{array}$ & $\begin{array}{c}\text { Executivo } \\
\text { Checagem }\end{array}$ & Distância \\
\hline Argentina & 70,4 & 44,3 & 26,1 \\
\hline Bolívia & 63,0 & 31,4 & 31,6 \\
\hline Brasil & 72,1 & 47,1 & 25,0 \\
\hline Chile & 58,4 & 31,4 & 27,0 \\
\hline Colômbia & 50,1 & 42,9 & 7,2 \\
\hline Costa Rica* & 39,2 & 44,3 & $-5,1$ \\
\hline El Salvador & 39,2 & 60,0 & $-20,8$ \\
\hline Equador & 60,5 & 52,9 & 7,6 \\
\hline Guatemala & 70,4 & 47,1 & 23,3 \\
\hline Haiti & 50,5 & 21,4 & 29,1 \\
\hline México & 27,9 & 51,4 & $-23,5$ \\
\hline Nicarágua* & 54,6 & 38,6 & 16,0 \\
\hline Panamá* $^{*}$ & 40,0 & 47,1 & $-7,1$ \\
\hline Paraguai & 48,0 & 47,1 & 0,9 \\
\hline Peru* & 55,1 & 40,0 & 15,1 \\
\hline Rep. Dominicana & 49,2 & 42,9 & 6,3 \\
\hline Uruguai & 70,4 & 44,3 & 26,1 \\
\hline Venezuela & 76,3 & 48,6 & 27,7 \\
\hline
\end{tabular}

Escala principal das variáveis: $\mathrm{B}=$ baixo, $\mathrm{M}=$ médio, $\mathrm{A}=$ alto; subescala da escala principal das variáveis: (a) $=$ alto, $(\mathrm{b})=$ baixo.

Escala dos resultados: I = equilíbrio, II = predomínio do Legislativo, III = predomínio do Executivo, IV = conflito.

* Países com apenas uma câmara legislativa.

A Tabela 6 condensa a Tabela 5 no que diz respeito à classificação em letra maiúscula, correspondente à escala principal das variáveis. Assim, praticamente metade dos países latinoamericanos presidencialistas apresenta no balanço entre poderes uma preponderância a favor do
Legislativo. Quatro casos constituem-se com preponderância do Executivo (Chile, Colômbia, México e Nicarágua), em quatro existe equilíbrio (Equador, Panamá, Paraguai, Peru) e em dois existe uma potencial situação de conflito (Brasil e Bolívia).

TABELA 6 - Equilíbrio e desequilíbrio entre independência e checagem por países presidencialistas da América Latina $(\mathrm{N}=17)$

\begin{tabular}{|c|c|c|c|}
\hline Equilíbrio & Predomínio do Legislativo & Predomínio do Executivo & Conflito \\
\hline & Argentina & & \\
& Costa Rica* & & \\
Equador $^{*}$ & El Salvador* & Chile & \\
Panamá* $^{*}$ & Guatemala & Colômbia & Bolívia \\
Paraguai $^{*}$ & Haiti & México & \\
Peru* $^{*}$ & Rep. Dominicana & Nicarágua* & \\
& Uruguai & & \\
\hline $4(22,2 \%)$ & Venezuela & $4(23,5 \%)$ & $2(11,8 \%)$ \\
\hline
\end{tabular}

* Países com apenas uma câmara legislativa. 
Agregando para análise o significado das letras minúsculas entre parênteses (subescala da escala principal das variáveis) da Tabela 5 , temos que na Argentina, apesar de existir predomínio Legislativo, existe um leve reequilíbrio a favor do Executivo tendo em vista que sua independência é média alta enquanto a checagem do Legislativo é média baixa. O Brasil, por seu turno, mesmo situando-se em potencial situação de conflito, apresenta discreta predominância legislativa, tendo em vista um poder de checagem situado em nível médio alto. $\mathrm{O}$ Executivo, por seu turno, apresenta um poder de checagem médio baixo.

No campo dos países onde o Executivo predomina, temos duas situações de tendência para quase-conflito (Chile e Colômbia) e um com leve tendência para o equilíbrio (Nicarágua). No campo dos países em equilíbrio existem leves tendências concorrendo para o desequilíbrio. Tendências que levam para a predominância do Executivo podem ser notados no Paraguai e no Equador, e tendências com leve predominância do Legislativo no Panamá e no Peru.

\section{BREVE CONCLUSÃO}

A teoria da separação de poderes propõe, normativamente, a divisão do poder em corpos separados e a capacidade de cada um desses corpos controlar o outro, devendo haver um equilíbrio entre os poderes de maneira a evitar o predomínio de um sobre o outro, possibilitando não apenas afastar o perigo da tirania, como, também, correlativamente, garantir a liberdade. De outro lado, a separação de poderes, caso seja efetiva, pode concorrer para a formação de sistemas democráticos menos centralizados, perfazendo o modelo consensualista. Assim, como comentou Mettenheim (2000), a separação de poderes, combinada com o presidencialismo, faria sentido dentro da afirmação da teoria da decisão e do processo político conforme a tradição pluralista, que enfatiza a necessidade do poder difuso. Dessa maneira, dentro do funcionamento do sistema de poder dividido, as instituições precisariam incentivar a iniciativa política, a negociação e a resolução de conflitos. A crença subjacente é de que com pelo menos dois centros de poder, ocupados por forças diferentes, o melhor governo pode ser produzido. Não chegamos a afirmar tanto, porque em situações de intensa polarização político-ideológica o processo dual pode se voltar contra a própria institucionalidade.
No entanto, é crível alcançar níveis substantivos de estabilidade política e governabilidade se os atores observarem a conclusão de Przeworski (1994): a democracia exige a adesão dos atores à regra do jogo.

A realidade constitucional da América Latina é dinâmica. Tal constatação indica que muitas modificações são introduzidas com o passar dos anos, transformando a correlação entre separação de poderes, sua independência e capacidade de checagem. Isso não impede contudo de apontarmos algumas conclusões mais gerais sobre o momento de vigência destas constituições.

Vimos que a maioria dos países latino-americanos apresenta, no período, predomínio do Legislativo. Estes países, em conjunto com aqueles que apresentam equilíbrio entre poderes, representa um expressivo contingente de $69,3 \%$ do total de países presidencialistas. A predominância do Legislativo é sancionada pelas teorias democráticas que alcançam soberania à representação, capacitada esta a fazer as leis. O equilíbrio é o resultado desejado pela teoria da separação de poderes. Contudo, existem importantes casos que desviam do estabelecido pelas teorias normativas (Brasil, México e Chile, por exemplo), ensejando a proposição de que certos dilemas institucionais devem ser superados para que o processo democrático se aperfeiçoe e se estabilize.

Nosso estudo exploratório mostrou que é possível estabelecer com mais acuidade os aspectos institucionais de separação, independência e checagem do poder. Os resultados alcançados nos permitem identificar que é possível descrever os desequilíbrios previstos na teoria. Nossa modelagem, contudo, não está pronta. $\mathrm{O}$ controle sobre os efeitos exige que as dimensões relativas ao jogo político da relação Executivo - Legislativo sejam incorporadas. Dessa maneira poderemos verificar até onde as variáveis de organização e constituição dos poderes são efetivamente importantes.

É claro que a institucionalidade dos poderes alocados para cada organismo do Estado e do Governo não pode substituir a ação política que redefine o espaço de cada um. Dessa forma, podemos entender as limitações desse exercício justamente porque existem casos e situações onde a ação política altera o desfecho colocado em perspectiva pelo quadro institucional, como por exemplo, o Peru de Fujimori. Também no campo 
da institucionalidade podemos ter a extensão das regulações constitucionais em forma de leis regulares, que implicam alteração do balanço Executivo-Legislativo-Judiciário. Porém, é a partir dessa institucionalidade que as diferentes forças políticas traçam suas estratégias. Isso é incontornável.

De outro lado, a existência de formatos institucionais algo diferentes, com possibilidades de gerarem resultados políticos também diferentes, demonstra que os presidencialismos existentes não podem ser considerados como um conjunto homogêneo quanto às suas implicações políticas. Além disso, o processo das transições para a democracia criou nos países da região soluções constitucionais diversas, apesar de alguma similitude aparente no emprego de certos instrumentos a disposição dos poderes.

A questão subseqüente a este breve estudo, além da necessidade de aprofundá-lo e torná-lo mais exaustivo, é justamente identificar, a partir desse quadro institucional diferenciado, quais são os efeitos reais e concretos por eles permitidos, se seus efeitos são marginais ou se, ao contrário, desempenham papel fundamental na ordenação da disputa política.

Recebido para publicação em 8 de outubro de 2001. Artigo aprovado em 23 de novembro de 2001.

Luís Gustavo Mello Grohmann (gustg@zaz.com.br) é Mestre em Ciência Política pela Universidade Federal do Rio Grande do Sul (UFRGS), Doutorando em Ciência Política no Instituto Universitário de Pequisas do Rio de Janeiro (IUPERJ) e Professor do Departamento de Sociologia e Política na Universidade Federal de Santa Maria (UFSM).

\section{REFERÊNCIAS BIBLIOGRÁFICAS}

AKZIN, B. 1972. Legislation. In : International Encyclopedia of the Social Sciences. New York/London : The Macmillan Company \& The Free Press/Collier-Macmillan Pub.

ARGENTINA. 1998. Constitución de la nación Argentina. Texto oficial de 1853 con las reformas de 1860, 1866, 1898, 1957 y 1994 ordenado por Ley n. 24.430. $8^{\text {a }}$ ed. actual. y amp. Buenos Aires : Astrea.

BAGEHOT, W. 1989. La constitution anglaise. Paris : Germer Baillière.

BOLÍVIA. 1967. Constitución de Bolívia, con reformas de 1994. www.georgetown.edu/ pdba/portuguese.html : 1999.

BOND, J. \& FLEISCHER, R. 1990. The President and the Legislative Arena. Chicago : University of Chicago Press.

BRASIL. 1988. Constituição da República Federativa do Brasil. $3^{a}$ ed. rev. e atual. São Paulo : Revista dos Tribunais.

CERQUEIRA, M. 1995. Controle do Judiciário : doutrina e controvérsia. Rio de Janeiro : Revan.

CHILE. 1980. Constitución política de la República de Chile, con reformas de 1997. www.georgetown.edu/pdba/portuguese.html :
1999.

.1994.Ley orgánica constitucional del Congreso Nacional de Chile. www.georgetown.edu/pdba/ portuguese.html : 1999.

COLOMBIA. 1991. Constitución política de Colombia, con reformas de 1997. www.georgetown.edu/pdba/portuguese.html : 1999.

COSTA RICA. 1949. Constitución política de la República de Costa Rica, con reformas de 1997. www.georgetown.edu/pdba/portuguese.html : 1999.

DIAMOND, A. 1986. Apropriada, embora democrática. In : GOLDWIN, R. A. \& SCHAMBRA, W. A. (orgs.). A Constituição norte-americana. Rio de Janeiro : ForenseUniversitária.

DUVERGER, M. 1970. Os partidos políticos. Rio de Janeiro : Zahar.

EL SALVADOR. 1982. Constitución politica de la República de El Salvador. www.georgetown.edu/ pdba/portuguese.html : 1999.

FISCHER, L. 1998. The Politics of Shared Power: Congress and the Executive. Texas (College Station) : The Texas University Press. 
FREITAS, R.C. 1997. Constitución de la República Oriental del Uruguay, de 1967, anotada y concordada con las reformas constitucionales parciales de 1989, 1994 y 1997. Buenos Aires : DEOF.

FUNG, A. \& WRIGHT, E. 1999. Experimentos em democracia deliberativa. Sociologias, Porto Alegre, ano 1, n. 2, p. 100-143, jul-dez.

GUATEMALA. 1986. Constitución política de la República de Guatemala, con reformas de 1993. www.georgetown.edu/pdba/portuguese.html : 1999.

HAITI. 1987. Constitution of Haiti. www.georgetown.edu/pdba/portuguese.html : 1999.

HIUTT, R. K. 1972. Legislative. In : International Encyclopedia of the Social Sciences. New York/London : The Macmillan Company \& The Free Press/Collier-Macmillan Pub.

JONES, C. O. 1995. Separate But Equal Branches : Congress and the Presidency. New Jersey: Chatam House.

1997. The American Presidency : a Separacionist Perspective. In : METTENHEIM, K. (ed.). Presidential Institutions and Democratic Politics : Comparing Regional and National contexts. Baltimore : Johns Hopkins University Press.

JONES, M. P. 1995. Electoral Laws and the Survival of Presidential Democracies. Notre Dame : University of Notre Dame Press.

KINZO, M. A. 1993. Radiografia do quadro partidário brasileiro. São Paulo : Fundação Konrad-Adenauer-Stiftung.

KORN, J. 1996. The Power of Separation : American Constituonalism and the Myth of the Legislative Veto. New Jersey : Princeton University Press.

LAMOUNIER, B. \& NOHLEN, D. (org.). 1993. Presidencialismo ou paramentarismo : perspectivas sobre a reorganização institucional brasileira. São Paulo : Loyola.

LAMOUNIER, B. (org.). 1991. A opção parlamentarista. São Paulo : IDESP/Sumaré.

LIJPHART, A. s/d. Democracies II : Forms of Government and Governement Performance in the Thirty-Six Countries. Digit.
LINZ, J. \& VALENZUELA, A. (eds.). 1994. The Failure of Presidential Democracy. Baltimore : Johns Hopkins University Press.

LOCKE, J. 1973. Segundo tratado sobre o governo. São Paulo : Abril Cultural.

MADISON, J., HAMILTON, A. \& JAY, J. 1993. Os artigos federalistas : 1787-1788. Rio de Janeiro : Nova Fronteira.

MAINWARING, S. \& SCULLY, T. R. (eds.). 1995. Building Democratic Institutions : Party Systems in Latin America. Stanford : Stanford University Press.

MAINWARING, S. \& SHUGART, M. S. (eds.). 1997. Presidentialism and Democracy in Latin America. Cambridge and New York : Cambridge University Press.

MAINWARING, S. 1991. Políticos, partidos e sistemas eleitorais : o Brasil numa perspectiva comparativa. Novos Estudos CEBRAP, São Paulo, n. 29, p. 34-58, mar.

1993. Democracia presidencialista multipartidária : o caso do Brasil. Lua Nova, São Paulo, n. 28-29, p. 21-74.

MAYHEW, D. R. 1991. Divided We Govern : Party Control, Lawmaking, and Investigations, 1946-1990. New Haven : Yale University Press.

METTENHEIM, K. (ed.). 1997. Presidential Institutions and Democratic Politics : Comparing Regional and National Contexts. Baltimore : Johns Hopkins University Press.

.2000. Democracy, the Separation of Powers and the Political Economy. Texto apresentado no $2^{\circ}$ Encontro da Associação Brasileira de Ciência Política, novembro. São Paulo : digit.

MÉXICO. 1917. Constitución política de Estados Unidos Mexicanos, con reformas de 1998. www.georgetown.edu/pdba/portuguese.html : 1999.

MONTESQUIEU, C. S. 1973. Do espirito das leis. São Paulo : Abril Cultural.

NEUSTADT, R. 1967. Presidential Power : the Politics of Leadership. New York : John Wiley \& Sons.

NICARÁGUA. 1987. Constitución de Nicarágua. www.georgetown.edu/pdba/portuguese.html : 1999. 
PANAMÁ. 1972. Constitución política de Panamá, con reformas de 1983 y 1994. www.georgetown.edu/pdba/portuguese.html : 1999.

PARAGUAY. 1992. Constitución de la República de Paraguay. www.georgetown.edu/pdba/ portuguese.html : 1999.

PERU. 1993. Constitución política de Peru. www.georgetown.edu/pdba/portuguese.html : 1999.

PETERS, B. G. 1997. The Separation of Powers in Parliamentary Systems. In : METTENHEIM, K. (ed.). Presidential Institutions and Democratic Politics : Comparing Regional and National Contexts. Baltimore : Johns Hopkins University Press.

POWELL JR., G. B. 1982. Contemporany Democracies : Participation, Stability and Violence. Cambridge : Cambrigde University Press.

PRZEWORSKI, A. 1994. Democracia e mercado no Leste Europeu e na América Latina. Rio de Janeiro : Relume-Dumará.

1999. O Estado e o cidadão.In : PEREIRA, L. C. B., WILHEIM, J. \& SOLA, L. (orgs.). Sociedade e Estado em transformação. São Paulo/Brasília : Unesp/ENAP.

REPÚBLICA DOMINICANA. 1994. Constitu- ción política de la República Dominicana. www.georgetown.edu/pdba/portuguese.html : 1999.

SARTORI, G. 1996. Engenharia constitucional : como mudam as constituições. Brasília : Edunb.

SHUGART, M. \& CAREY, J. 1992. Presidents and Assemblies : Constitutional Design and Electoral Dynamics. Cambridge : Cambridge University Press.

SOLA, L. 1999. Reformas do Estado para qual democracia? O lugar da política. In : PEREIRA, L. C. B., WILHEIM, J. \& SOLA, L. (orgs.). Sociedade e Estado em transformação. São Paulo/Brasília : Unesp/ENAP.

TRINDADE, H. (org.). 1992. Reforma eleitoral e representação política: Brasil anos 90 . Porto Alegre : Editora da Universidade.

TSEBELIS, G. 1998. Jogos ocultos : escolha racional no campo da política comparada. São Paulo : Edusp.

VENEZUELA. 1961. Constitución política de la República de Venezuela, con reformas de 1983. www.georgetown.edu/pdba/portuguese.html : 1999.

VILE, M. J. C. 1998. Constitutionalism and the Separation of Powers. Indianapolis : Liberty Fund. 


\section{ANEXO I}

TABELA A-1 - Separação de poderes (em \%)

\begin{tabular}{|c|c|c|c|c|c|c|c|}
\hline \multirow{2}{*}{ País } & \multirow{2}{*}{$A$} & \multirow{2}{*}{ B } & \multirow{2}{*}{ C } & \multirow{2}{*}{ D } & \multicolumn{2}{|c|}{$\mathrm{E}$} & \multirow{2}{*}{$\begin{array}{c}\text { Total } \\
\text { Normalizado }\end{array}$} \\
\hline & & & & & 1 & 2 & \\
\hline Argentina & 66,6 & 100 & 0 & 66,6 & 40 & 40 & 52,2 \\
\hline Bolívia & 58,3 & 100 & 80 & 88,8 & 20 & 80 & 71,2 \\
\hline Brasil & 66,6 & 100 & 40 & 66,6 & 60 & 80 & 68,9 \\
\hline Chile & 70,8 & 100 & 80 & 77,7 & 40 & 60 & 71,4 \\
\hline Colômbia & 66,6 & 100 & 60 & 100 & 20 & 0 & 57,8 \\
\hline Costa Rica* & 66,6 & 100 & 20 & 33,3 & 20 & 40 & 46,7 \\
\hline El Salvador* & 66,6 & 100 & 60 & 88,8 & 20 & 20 & 59,3 \\
\hline Equador* & 66,6 & 100 & 80 & 100 & 20 & 0 & 61,1 \\
\hline Guatemala & 75 & 100 & 80 & 100 & 20 & 20 & 65,8 \\
\hline Haiti & 58,3 & 66,6 & 60 & 66,6 & 20 & 20 & 48,6 \\
\hline México & 66,6 & 100 & 0 & 66,6 & 20 & 20 & 45,6 \\
\hline Nicarágua* & 58,3 & 100 & 80 & 100 & 20 & 20 & 63,1 \\
\hline Panamá* & 66,6 & 100 & 80 & 55,5 & 20 & 0 & 53,7 \\
\hline Paraguai & 83,3 & 100 & 80 & 55,5 & 20 & 40 & 63,1 \\
\hline Peru $^{*}$ & 100 & 66,6 & 80 & 77,7 & 20 & 0 & 57,4 \\
\hline Rep. Dominicana & 75 & 100 & 40 & 100 & 20 & 20 & 59,2 \\
\hline Uruguai & 66,6 & 66,6 & 0 & 66,6 & 20 & 40 & 43,3 \\
\hline Venezuela & 62,5 & 100 & 20 & 100 & 20 & 40 & 57,1 \\
\hline
\end{tabular}

* Países unicamerais

$\mathrm{A}=$ Origem do mandato

$B=$ Independência do mandato

C = Fiscalização das contas

$\mathrm{D}=$ Independência financeira do poder

$\mathrm{E} 1$ = Atribuições constitucionais exclusivas do Executivo

$\mathrm{E} 2$ = Atribuições constitucionais exclusivas do Legislativo

TABELA A-2 - Independência dos poderes (em \%)

\begin{tabular}{|c|c|c|c|c|c|c|c|c|}
\hline País & A & B & C & D & E & F & G & Total Normalizado \\
\hline Argentina & 39,5 & 66,6 & 59,2 & 33,3 & 40 & 33,3 & 40 & 47,4 \\
\hline Bolívia & 44,4 & 46,6 & 33,3 & 55,5 & 0 & 83,3 & 0 & 36,7 \\
\hline Brasil & 44,4 & 73,3 & 59,2 & 44,4 & 90 & 50 & 60 & 65,1 \\
\hline Chile & 86,4 & 73,3 & 33,3 & 55,5 & 40 & 66,6 & 40 & 61,6 \\
\hline Colômbia $^{4}$ & 44,4 & 40 & 29,6 & 55,5 & 30 & 100 & 40 & 47 \\
\hline Costa Rica* $^{*}$ & 22,2 & 66,6 & 3,7 & 0 & 0 & 50 & 0 & 24 \\
\hline El Salvador* & 12,3 & 26,6 & 3,7 & 0 & 0 & 50 & 0 & 13,6 \\
\hline Equador* $^{*} 0$ & 66,6 & 33,3 & 44,4 & 0 & 83,3 & 40 & 34,6 \\
\hline Guatemala $^{*} 12,3$ & 66,6 & 33,3 & 0 & 0 & 50 & 80 & 33,3 \\
\hline Haiti & 86,4 & 86,6 & 3,7 & 0 & 0 & 50 & 0 & 41,4 \\
\hline México $^{22,2}$ & 6,6 & 3,7 & 0 & 20 & 50 & 0 & 15,7 \\
\hline Nicarágua* & 44,4 & 73,3 & 0 & 0 & 30 & 83,3 & 0 & 39,2 \\
\hline Panamá* $^{*}$ & 17,2 & 60 & 3,7 & 0 & 10 & 0 & 0 & 18,5 \\
\hline Paraguai $^{*} 44,4$ & 46,6 & 33,3 & 77,7 & 0 & 50 & 40 & 39,7 \\
\hline
\end{tabular}




\section{A SEPARAÇÃO DE PODERES EM PAÍSES PRESIDENCIALISTAS}

\begin{tabular}{|c|c|c|c|c|c|c|c|c|}
\hline Peru* $^{\star}$ & 44,4 & 20 & 29,6 & 0 & 70 & 100 & 0 & 41,3 \\
\hline Rep. Dominicana & 44,4 & 66,6 & 0 & 0 & 0 & 50 & 0 & 28,2 \\
\hline Uruguai & 86,4 & 66,6 & 33,3 & 66,6 & 0 & 83,3 & 40 & 54,8 \\
\hline Venezuela & 44,4 & 100 & 29,6 & 0 & 0 & 83,3 & 0 & 41,6 \\
\hline
\end{tabular}

* Países unicamerais

$A=$ Iniciativa de leis

$B=$ Decisão legislativa

C = Recursos de tempo para tramitação

$\mathrm{D}=$ Urgência de projetos

$\mathrm{E}=$ Decretos Legislativos / delegação legislativa

$\mathrm{F}=$ Decreto estado de sítio

$\mathrm{G}=$ Convocação de plebiscito

TABELA A-3 - Checagem dos poderes (em \%)

\begin{tabular}{|c|c|c|c|}
\hline País & Executivo & Legislativo & Total Normalizado \\
\hline Argentina & 44,2 & 48,1 & 46,2 \\
\hline Bolívia & 31,4 & 25,9 & 28,6 \\
\hline Brasil & 47,1 & 51,8 & 49,5 \\
\hline Chile & 31,4 & 40,7 & 36,1 \\
\hline Colômbia & 42,8 & 44,4 & 43,6 \\
\hline Costa Rica* & 44,2 & 48,1 & 46,2 \\
\hline El Salvador* & 60 & 40,7 & 50,4 \\
\hline Equador* & 52,8 & 37 & 44,9 \\
\hline Guatemala $^{*}$ & 47,1 & 48,1 & 47,6 \\
\hline Haiti & 21,4 & 59,2 & 40,3 \\
\hline México & 51,4 & 44,4 & 47,9 \\
\hline Nicarágua* & 38,5 & 14,8 & 26,7 \\
\hline Panamá* $^{*}$ & 47,1 & 51,8 & 49,5 \\
\hline Paraguai $^{*}$ & 47,1 & 44,4 & 45,8 \\
\hline Peru* & 39,9 & 62,9 & 51,5 \\
\hline Rep. Dominicana & 42,8 & 51,8 & 47,4 \\
\hline Uruguai $^{*}$ & 44,2 & 66,6 & 55,5 \\
\hline Venezuela $^{*}$ & 48,5 & 51,8 & 50,2 \\
\hline
\end{tabular}

* Países unicamerais

TABELA A-4 - Independência do Executivo (em \%)

\begin{tabular}{|c|c|c|c|c|c|c|c|}
\hline País & Iniciativa & $\begin{array}{c}\text { Recurso } \\
\text { Tempo }\end{array}$ & Urgência & Decreto & $\begin{array}{c}\text { Estado de } \\
\text { Sítio }\end{array}$ & Plebiscito & $\begin{array}{c}\text { Total } \\
\text { Normalizado }\end{array}$ \\
\hline Argentina & 66,6 & 50 & 16,6 & 40 & 25 & 33 & 60,4 \\
\hline Bolívia & 100 & 25 & 27,7 & 0 & 50 & 0 & 52,9 \\
\hline Brasil & 100 & 50 & 22,2 & 90 & 50 & 0 & 81,5 \\
\hline Chile & 100 & 50 & 27,7 & 40 & 50 & 33 & 78,5 \\
\hline Colômbia & 100 & 50 & 27,7 & 30 & 50 & 33 & 75,9 \\
\hline Costa Rica* $^{*}$ & 66,6 & 25 & 0 & 0 & 25 & 0 & 30,5 \\
\hline El Salvador* & 66,6 & 25 & 0 & 0 & 25 & 0 & 30,5 \\
\hline Equador* & 66,6 & 50 & 22,2 & 0 & 50 & 33 & 57,9 \\
\hline
\end{tabular}




\begin{tabular}{c|c|c|c|c|c|c|c|}
\hline Guatemala & 66,6 & 25 & 0 & 0 & 50 & 33 & 45,6 \\
\hline Haiti & 100 & 25 & 0 & 0 & 50 & 0 & 45,7 \\
\hline México & 66,6 & 0 & 0 & 20 & 50 & 0 & 35,7 \\
\hline Nicarágua* $^{\text {Panamá* }}$ & 100 & 0 & 0 & 30 & 50 & 0 & 47 \\
\hline Paraguai $^{\text {Peru* }}$ & 100 & 25 & 0 & 10 & 0 & 0 & 35,2 \\
\hline $\begin{array}{c}\text { Rep. } \\
\text { Dominicana }\end{array}$ & 100 & 50 & 38,8 & 0 & 50 & 0 & 62,4 \\
\hline Uruguai & 100 & 50 & 0 & 70 & 50 & 0 & 61,8 \\
\hline Venezuela & 100 & 0 & 0 & 0 & 25 & 0 & 32,6 \\
\hline
\end{tabular}

* Países unicamerais

TABELA A-5 - Independência do Legislativo (em \%)

\begin{tabular}{c|c|c|c|c|c|c|}
\hline País & Iniciativa & $\begin{array}{c}\text { Recurso } \\
\text { Tempo }\end{array}$ & Decisão & $\begin{array}{c}\text { Estado de } \\
\text { Sítio }\end{array}$ & Plebiscito & Total Normalizado \\
\hline Argentina & 66,6 & 50 & 72,2 & 12,5 & 33 & 70,4 \\
\hline Bolívia & 66,6 & 50 & 55,5 & 37,5 & 0 & 63 \\
\hline Brasil & 66,6 & 50 & 77,7 & 12,5 & 33 & 72,1 \\
\hline Chile & 66,6 & 25 & 77,7 & 25 & 0 & 58,4 \\
\hline Colômbia & 66,6 & 0 & 50 & 50 & 0 & 50,1 \\
\hline Costa Rica* $^{*}$ & 33,3 & 0 & 72,2 & 25 & 0 & 39,2 \\
\hline El Salvador* & 66,6 & 0 & 38,8 & 25 & 0 & 39,2 \\
\hline Equador* & 66,6 & 25 & 72,2 & 37,5 & 0 & 60,5 \\
\hline Guatemala & 66,6 & 50 & 72,2 & 12,5 & 33 & 70,4 \\
\hline Haiti & 66,6 & 0 & 88,8 & 12,5 & 0 & 50,5 \\
\hline México & 33,3 & 25 & 22,2 & 12,5 & 0 & 27,9 \\
\hline Nicarágua* & 66,6 & 0 & 77,7 & 37,5 & 0 & 54,6 \\
\hline Panamá* & 66,6 & 0 & 66,6 & 0 & 0 & 40 \\
\hline Paraguai & 66,6 & 25 & 55,5 & 12,5 & 0 & 47,9 \\
\hline Peru* & 100 & 0 & 33,3 & 50 & 0 & 55,1 \\
\hline Rep. & 66,6 & 0 & 72,2 & 25 & 0 & 49,2 \\
\hline Dominicana & 66,6 & 25 & 72,2 & 37,5 & 33 & 70,4 \\
\hline Uruguai & 66,6 & 50 & 100 & 37,5 & 0 & 76,3 \\
\hline Venezuela & & & & & & \\
\hline
\end{tabular}

* Países unicamerais

\section{ANEXO II - VARIÁVEIS E SUBVARIÁVEIS}

QUADRO A-1 - Variável: Separação

\begin{tabular}{|l|l|l|}
\hline \multicolumn{1}{|c|}{ Subvariável } & \multicolumn{1}{|c|}{ Indicador } & \multicolumn{1}{c|}{ Valor } \\
\hline 1. Origem do Poder & $\begin{array}{l}\text { Para cada poder, qual a origem } \\
\text { do mandato }\end{array}$ & $\begin{array}{l}\text { Executivo [E] + Câmara Alta [CA] ou } \\
\text { Câmara Baixa [CB] + CA (1); E + CB + } \\
\text { Judiciário [J] + outras (2); outras (3); } \\
\text { eleitoral + outras (4); eleitoral (5) }\end{array}$ \\
\hline
\end{tabular}




\begin{tabular}{|c|c|c|}
\hline 2. Mandato Independente & $\begin{array}{l}\text { Para cada poder, se seu mandato } \\
\text { não pode ser interrompido por } \\
\text { outro poder }\end{array}$ & Sim (1); Não (0) \\
\hline $\begin{array}{l}\text { 3.Independência } \\
\text { financeira do poder }\end{array}$ & $\begin{array}{l}\text { Para cada poder, independência } \\
\text { orçamentária }\end{array}$ & $\begin{array}{l}\text { Dependência total (1); semi- } \\
\text { independente, com \% mínimo, decisão do } \\
\text { outro poder (2); independente mas com } \\
\text { decisão conjunta não normatizada, via } \\
\text { orçamento (3); total independência (4) }\end{array}$ \\
\hline $\begin{array}{l}\text { 4.Atribuições } \\
\text { constitucionais exclusivas }\end{array}$ & $\begin{array}{l}\text { Se o poder tem atribuições } \\
\text { constitucionais exclusivas de } \\
\text { cunho Legislativo, Executivo, } \\
\text { Judiciário, Orçamentário, outras. }\end{array}$ & Sim (1); Não (0) \\
\hline
\end{tabular}

QUADRO A-2 - Variável: Independência

\begin{tabular}{|c|c|c|}
\hline Subvariáveis & Indicador & Valores \\
\hline $\begin{array}{l}\text { 1. Iniciativa de lei, por poder } \\
\text { 1.A. de leis constitucionais } \\
\text { 1.B. de leis orçamentárias } \\
\text { 1.C. de leis ordinárias }\end{array}$ & $\begin{array}{l}\text { 1.A. O poder pode ou não apresentar } \\
\text { projeto sobre matéria constitucional } \\
\text { 1.B. idem sobre matéria orçamentária } \\
\text { 1.C. idem sobre matéria ordinária }\end{array}$ & Sim (1); Não (0) \\
\hline $\begin{array}{l}\text { 2. Quorum para decisão } \\
\text { legislativa } \\
\text { 2.A. para emendas } \\
\text { constitucionais } \\
\text { 2.B. para leis orçamentárias } \\
\text { 2.C. para leis ordinárias }\end{array}$ & $\begin{array}{l}\text { 2.A. Quorum em plenário para votar } \\
\text { projeto de lei sobre emenda } \\
\text { constitucional } \\
\text { 2.B. idem sobre orçamento } \\
\text { 2.C. idem sobre matérias ordinárias }\end{array}$ & $\begin{array}{l}\text { Maioria Relativa (4); Maioria } \\
\text { Absoluta (3); } 3 / 5 \text { absoluta } \\
\text { (2); 2/3 absoluta (1) }\end{array}$ \\
\hline $\begin{array}{l}\text { 3. Recursos de tempo } \\
\text { 3.A. Solicitação de urgência } \\
\text { para projetos, por poder } \\
\text { 3.B. convocação de sessão } \\
\text { extraordinária, por poder }\end{array}$ & $\begin{array}{l}\text { 3.A. Se o poder tem prerrogativa de } \\
\text { pedir urgência par projetos de lei } \\
\text { 3.B. Se o poder tem prerrogativa de } \\
\text { pedir convocação de sessão } \\
\text { extraordinária }\end{array}$ & $\operatorname{Sim}(1)$; Não (0) \\
\hline $\begin{array}{l}\text { 4. Urgência do Executivo } \\
\text { 4.A. trâmite do projeto em caso } \\
\text { de não exame pelo Legislativo } \\
\text { 4.B. momento do pedido de } \\
\text { urgência } \\
\text { 4.C. limitação ou não do } \\
\text { número de projetos com pedido } \\
\text { de urgência } \\
\text { 4.D. pedido de urgência pode } \\
\text { ser derrubado } \\
\text { 4.E. quorum para derrubada da } \\
\text { urgência }\end{array}$ & $\begin{array}{l}\text { 4.A. Qual o trâmite do projeto caso o } \\
\text { Legislativo não o examine pelo tempo } \\
\text { estabelecido } \\
\text { 4.B. Em qual momento do trâmite do } \\
\text { projeto de lei pode ser solicitada a } \\
\text { urgência } \\
\text { 4.C. Se existe limitação ou não do } \\
\text { número de projetos com pedido de } \\
\text { urgência } \\
\text { 4.D. Se o pedido de urgência pode ser } \\
\text { ou não derrubado pelo plenário do } \\
\text { Legislativo } \\
\text { 4.E. Qual o quorum para o plenário do } \\
\text { Legislativo derrubar o pedido de } \\
\text { urgência }\end{array}$ & $\begin{array}{l}\text { 4.A. Entra na pauta de } \\
\text { imediato (1); projeto é } \\
\text { aprovado (2) } \\
\text { 4.B. No início do processo } \\
\text { (1); em qualquer parte do } \\
\text { trâmite (2) } \\
\text { 4.C. sim (0); não (1) } \\
\text { 4.D. sim (0); não (1) } \\
\text { 4.E Não se aplica [nsa] (0); } \\
\text { 2/3 relativo (1); } 3 / 5 \text { absoluto } \\
\text { (2); } 2 / 3 \text { absoluto (3). }\end{array}$ \\
\hline $\begin{array}{l}\text { 5. Decreto do Executivo e } \\
\text { delegação do Legislativo } \\
\text { 5.A. controle da vigência do } \\
\text { decreto Legislativo pelo poder } \\
\text { Legislativo }\end{array}$ & $\begin{array}{l}\text { 5.A. O Legislativo pode ou não impedir a } \\
\text { entrada em vigor de decreto Legislativo } \\
\text { 5.B. Qual área de atuação do decreto } \\
\text { 5.C. Se o Executivo pode reeditar ou } \\
\text { não o decreto }\end{array}$ & $\begin{array}{l}\text { 5.A. Não há decreto (0); } \\
\text { efeito do decreto com } \\
\text { necessidade de decisão do } \\
\text { Legislativo (1); efeito sem } \\
\text { necessidade de decisão do } \\
\text { Legislativo (2) }\end{array}$ \\
\hline
\end{tabular}




\begin{tabular}{|c|c|c|}
\hline $\begin{array}{l}\text { 5.B. área de atuação do } \\
\text { decreto Legislativo } \\
\text { 5.C. poder de reedição do } \\
\text { decreto Legislativo } \\
\text { 5.D. existência de lei delegada } \\
\text { e amplitude da lei delegada }\end{array}$ & $\begin{array}{l}\text { 5.D. Se existe lei delegada e qual sua } \\
\text { amplitude }\end{array}$ & $\begin{array}{l}\text { 5.B. Qualquer área } \\
\text { excluindo algumas (1); } \\
\text { qualquer área menos } \\
\text { constitucional (2); qualquer } \\
\text { área (3). } \\
\text { 5.C. sim (1); não (0) } \\
\text { 5.D. Não existe lei delegada } \\
\text { (0); existe mas só para } \\
\text { casos administrativos ou } \\
\text { emergenciais (1); existe e é } \\
\text { ampla (2) }\end{array}$ \\
\hline $\begin{array}{l}\text { 6. Decreto Estado de sítio } \\
\text { 6.A. quem decreta estado de } \\
\text { sítio } \\
\text { 6.B. posição do poder que não } \\
\text { decreta }\end{array}$ & $\begin{array}{l}\text { 6.A. Qual poder decreta Estado de sítio } \\
\text { 6.B. Qual é a posição do poder que não } \\
\text { decreta }\end{array}$ & $\begin{array}{l}\text { 6.A. Congresso + E (1); E } \\
\text { (2); } \\
\text { 6.B. Decide antes da } \\
\text { vigência (1); tanto pode } \\
\text { decidir antes quanto depois } \\
\text { (2); decide depois da } \\
\text { vigência (3) }\end{array}$ \\
\hline $\begin{array}{l}\text { 7. Convocação de consultas } \\
\text { nacionais } \\
\text { 7.A. quem convoca } \\
\text { 7.B. área do tema de } \\
\text { convocação }\end{array}$ & $\begin{array}{l}\text { 7.A. Quem convoca, por poder } \\
\text { 7.B Área do tema de convocação }\end{array}$ & $\begin{array}{l}\text { 7.A. Sim (1); não }(0) \\
\text { 7.B Temas constitucionais } \\
\text { (1); qualquer tema (2) }\end{array}$ \\
\hline
\end{tabular}

QUADRO A-3 - Variável: Checagem

\begin{tabular}{|c|c|}
\hline Subvariáveis & Indicador* \\
\hline Executivo & $\begin{array}{l}\text { 1. existência do poder de veto } \\
\text { 2. poder de dissolver Legislativo } \\
\text { 3. direito de participação ministerial em sessões legislativas }\end{array}$ \\
\hline Veto & $\begin{array}{l}\text { 1. se existe veto total } \\
\text { 2. tipo de veto parcial: ilimitado (2); limitado a partes inteiras (1); nsa não tem (0) } \\
\text { 3. quorum para derrubar o veto: MR (1) } 3 / 5 \text { relativa (2); } 2 / 3 \text { relativa (3); MA (4); } \\
3 / 5 \text { absoluta (5); } 2 / 3 \text { absoluta (6) } \\
\text { 4. se existe veto à matéria constitucional } \\
\text { 5. participação das câmaras para derrubar o veto: basta uma (1); precisa das } \\
\text { duas, em separado (2), Congresso (3). } \\
\text { 6. forma de exame do veto pelo Legislativo : em bloco (1); destaque (2); nsa (0) } \\
\text { 7. procedimento para veto sem apreciação dentro do tempo constitucional pelas } \\
\text { câmaras: automaticamente aprovado (2); incluído na ordem do dia (1); espera } \\
\text { pela ordem do dia do Legislativo (0) } \\
\text { 8. se partes não vetadas são transformadas imediatamente em lei }\end{array}$ \\
\hline Câmara Baixa & $\begin{array}{l}\text { 1. existência de comissão de investigação exclusiva } \\
\text { 2. pedidos e convocação de sessão de informações sobre outro poder } \\
\text { 3. poder de apreciação de contas } \\
\text { 4. abrir processo para julgamento } \\
\text { 5. dar autorização par preenchimento de cargos } \\
\text { 6. obrigatoriedade de receber comunicação de planos governamentais } \\
\text { 7. expedir autorização sobre matérias diversas, como guerra/paz, autorizar } \\
\text { viagens etc. } \\
\text { 8. expedir voto de censura ou confiança sobre presidente } \\
\text { 9. expedir voto de censura ou confiança sobre ministros e equipe presidencial } \\
\text { 10. solicitar demissão do presidente } \\
\text { 11. proceder julgamento de contas dos outros poderes } \\
\text { 12. julgar presidente } \\
\text { 13. julgar ministros e equipe presidencial } \\
\text { 14. capacidade de impedir atos inconstitucionais do Executivo } \\
\end{array}$ \\
\hline
\end{tabular}


A SEPARAÇÃO DE PODERES EM PAÍSES PRESIDENCIALISTAS

\begin{tabular}{|l|l|}
\hline Câmara Alta & De 1 a 14 idem acima \\
\hline
\end{tabular}

* Variam entre sim (1) e não (0), exceto a subvariável Veto. 